\title{
Sustainability of High Arctic Ponds in a Polar Desert Environment
}

\author{
ANNA ABNIZOVA ${ }^{1,2}$ and KATHY L. YOUNG
}

(Received 6 January 2009; accepted in revised form 23 May 2009)

\begin{abstract}
Arctic wetland environments are sensitive to ongoing climate change as seen by the recent loss of lakes and ponds in southern Alaska, Siberia, and northern Ellesmere Island, Canada. A clearer picture of the mechanisms accounting for these losses or the persistence of ponds is presently required. To better understand and quantify the hydrologic processes that are leading to the sustainability or demise of High Arctic ponds, a detailed study was conducted during the summer seasons of 2005 and 2006 at Somerset Island, Nunavut ( $\left.72^{\circ} 43^{\prime} \mathrm{N}, 94^{\circ} 15^{\prime} \mathrm{W}\right)$. A water balance framework that quantifies water inputs, losses, and storage was employed on four ponds situated in three broad geomorphic areas (coastal, bedrock, and glacial terrain, which includes plateau and moraine). The initial snow cover amount influenced the water level pattern for the summer season. Large end-of-winter snow accumulations in the deep Bedrock pond ensured large initial water storage and seasonal sustainability despite variable climatic conditions and a coarse substrate, which encouraged subsurface outflow. Connectivity to a stream draining an upland area and a melting late-lying snowbed nearby allowed the small Moraine pond to maintain stable water levels throughout both years. Sandy soils typical of the Coastal and Plateau ponds favored seepage and subsurface water losses, leading to desiccation of these ponds during dry periods. Lateral water losses from the Coastal pond were enhanced by the presence of a downslope frost crack that formed a steep hydraulic gradient with the pond. High initial snowfall and substantial rain maintain pond water levels, but in years with low snowfall and dry conditions, ponds are vulnerable to disappearance unless a range of dependable hydrological linkages exists.
\end{abstract}

Key words: Arctic hydrology, climate change, connectivity, low-gradient wetland, sustainability

RÉSUMÉ. Les milieux humides de l'Arctique sont sensibles aux changements climatiques continus, tel que l'atteste la perte récente de lacs et d'étangs du sud de l'Alaska, de la Sibérie et du nord de l'île d'Ellesmere, au Canada. À l'heure actuelle, il faut obtenir une meilleure idée des mécanismes à la source de ces pertes ou à la source de la persistance des étangs. Afin de mieux comprendre et de quantifier les processus hydrologiques qui entraînent la durabilité ou la disparition des étangs de l'Extrême

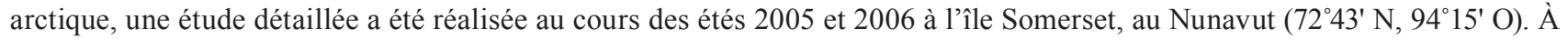
quatre étangs situés dans trois grandes zones géomorphologiques (côtière, roche de fond et terrain glaciaire, ce qui comprend plateaux et moraines), on a utilisé un cadre de référence de bilan hydrique quantifiant les gains, les pertes et le stockage d'eau. La quantité de couverture de neige initiale exerçait une influence sur le modèle de niveau d'eau pendant la saison d'été. Les fortes accumulations de neige en fin d'hiver dans la profonde roche de fond des étangs donnaient lieu à un important stockage initial de l'eau et à la durabilité saisonnière malgré des conditions climatiques variables et un substrat grossier, ce qui favorisait l'écoulement en-dessous de la surface. La connectivité à un cours d'eau drainant une zone plus élevée et un lit de neige tardif et fondant situé tout près a permis au petit étang de la moraine de maintenir des niveaux d'eau stables au cours des deux années. Les sols sableux typiques des étangs de la côte et du plateau favorisaient le suintement et la perte d'eau en-dessous de la surface, ce qui a mené à la dessiccation de ces étangs pendant les périodes sèches. Les pertes latérales d'eau de l'étang côtier étaient rehaussées par la présence d'une gélivure de pente descendante qui formait un gradient hydraulique prononcé dans l'étang. D'importantes chutes de neige initiales et une pluie considérable ont pour effet de maintenir les niveaux d'eau des étangs, mais pendant les années où les chutes de neige sont faibles et où les conditions sont sèches, les étangs sont susceptibles de disparaître à moins qu'il n'existe une gamme de liaisons hydrologiques fiables.

Mots clés : hydrologie de l'Arctique, changement climatique, connectivité, milieu humide à faible gradient, durabilité

Traduit pour la revue Arctic par Nicole Giguère.

\section{INTRODUCTION}

The High Arctic is described as a polar desert with mostly barren land surfaces, low amounts of precipitation, and intense and persistent coldness (Woo et al., 2006). In the areas where local water supplies exceed water losses in the thaw season, Arctic freshwater ecosystems such as wetlands can be found (Woo and Young, 2003). These wetlands have a high biodiversity and provide a rich and clean local supply of water in an otherwise arid landscape (Woo and Young,

\footnotetext{
${ }^{1}$ Department of Geography, York University, Toronto, Ontario M3J 1P3, Canada

${ }^{2}$ Corresponding author: anna_abnizova@yahoo.ca

(C) The Arctic Institute of North America
} 
2006). Ponds and lakes generally make up the largest terrain types here and serve as important resting and feeding grounds for migratory birds (Latour et al., 2005; Brown and Young, 2006). Their position in these low-gradient wetland basins, as a series of depressions, allows water to be stored, evaporated, and transmitted during periods of snowmelt and heavy rainfall events (e.g., Bowling et al., 2003; Brown and Young, 2006).

Recently, High Arctic ponds have been recognized as being highly sensitive to a changing climate (e.g., Brown and Young, 2006; Smol and Douglas, 2007). Brown and Young (2006), using past and present aerial photographs, showed that small ponds have disappeared from a polar desert landscape when late-lying upslope snowbeds have melted out. Smol and Douglas (2007) document the rapid drying out of several ponds in a polar oasis environment on northern Ellesmere in response to an extremely warm and dry summer. In the same vicinity, Keatley et al. (2007) indicate that the water chemistry of ponds and lakes has changed over time: these ponds and lakes now have higher $\mathrm{pH}$ and conductivities relative to polar desert ponds, even those a short distance away. Keatley et al. (2007) suggest that these changes are due to enhanced runoff, more evaporation, and greater vegetation changes, though direct measurements were not made. Analyses of remotely sensed imagery near Council, Alaska (1950s to 2002) show a dramatic reduction in the size and number of more than 10000 ponds with most of the change coming after the 1970s. The recent warming has triggered the drainage and disappearance of many ponds in the discontinuous permafrost zone (e.g., Fitzgerald and Riordan, 2003; Yoshikawa and Hinzman, 2003; Smith et al., 2005), but conversely, an increase in lake area in continuous permafrost zones of Siberia that is due to thermokarst and subsequent infilling of the newly formed depressions with water (Smith et al., 2005). Despite the recognition of these disparate results in different regions, few studies have tried to understand the full range of responses to shifting climatic conditions found in ponds existing within extensive High Arctic wetland systems. Nor has much attention been focused on the environmental factors or landscape linkages that sustain some ponds through these variable climatic conditions, while other ponds and lakes are drying out, disappearing, or transitioning into other landforms, such as wet meadows.

The water balance plays an important role in the survival of ponds in the context of climate change. For some ponds, survival often depends heavily on the local enrichment of water, supplied by one or more hydrologic linkages with the surrounding landscape. Pond linkages with the landscape are not consistent and may vary from year to year (Woo and Guan, 2006). Hence, this study aims to improve our understanding of the hydrology and sustainability of ponds in an extensive High Arctic wetland environment influenced by a polar desert climatic regime. We applied a detailed water balance framework to a selection of ponds that characterize a large part of post-glacial terrain near Creswell Bay, Somerset Island. Overall, this study examined a total of 12

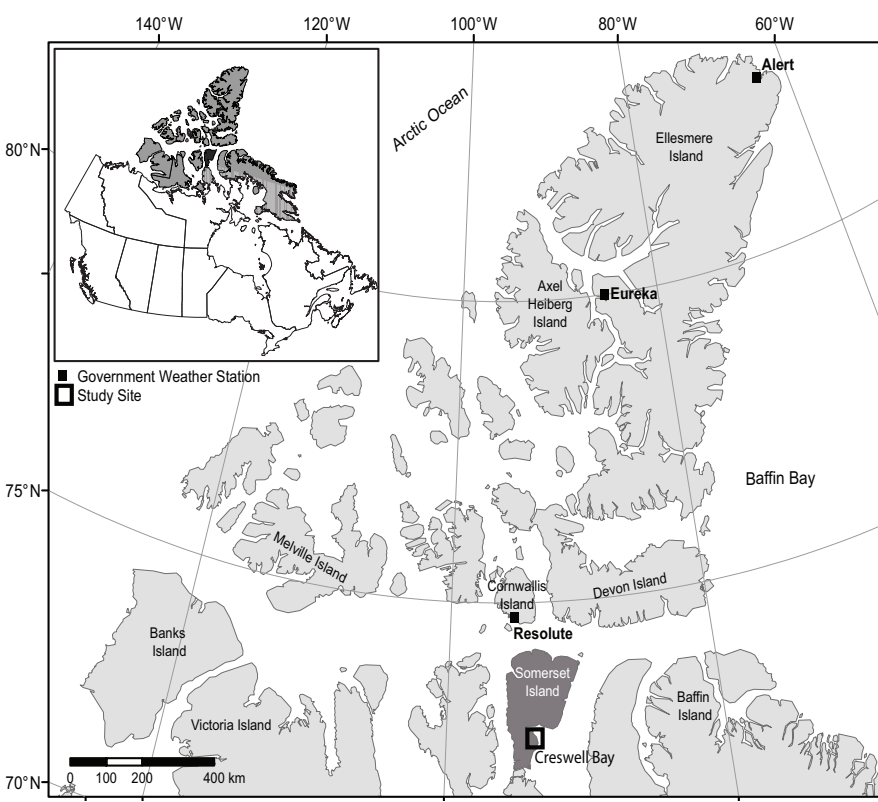

FIG. 1. Location of study area $\left(72^{\circ} 43^{\prime} \mathrm{N} 94^{\circ} 15^{\prime} \mathrm{W}\right)$ near Creswell Bay, Somerset Island, Nunavut. Inset shows location of Somerset Island within the Canadian High Arctic Islands.

ponds, which ranged in size from small $\left(149 \mathrm{~m}^{2}\right)$ to large $\left(6161 \mathrm{~m}^{2}\right)$. Here, we report on the four ponds for which we have the most comprehensive data set, and which provide a good representation of the processes controlling pond hydrology in this environment.

Specifically, this study (1) examines the critical hydrologic and landscape factors that are important in sustaining ponds through variable short-term fluctuating weather conditions and possibly long-term climatic shifts; (2) examines the relative importance of lateral water sources (e.g., meltwater from late-lying snowbeds, streams, and other linear waterways, such as frost cracks) in the maintenance and the survival of these polar desert ponds; and (3) assesses the role played by climate (radiation, temperature, precipitation), as opposed to the landscape setting, in the hydrology and sustainability of these polar desert ponds.

\section{STUDY AREA}

The study took place near Creswell Bay, Somerset Island, Nunavut $\left(72^{\circ} 43^{\prime} \mathrm{N} 94^{\circ} 15^{\prime} \mathrm{W}\right)$, an area of continuous permafrost (Fig. 1). The extensive wetland south of Creswell Bay is composed of a coastal section adjacent to the bay, which has undergone isostatic uplift and is characterized by coastal beach sediments, and ground cover composed mainly of limestone rock (Brown and Young, 2006). The southern zone of this wetland is rocky, poorly drained, and generally well vegetated. There are no long-term climate data for Somerset Island, but the local climate is described by Rust and Coakley (1970) as similar to that of Resolute Bay, a government weather station located about $100 \mathrm{~km}$ to the north on the southwest shore of Cornwallis Island 


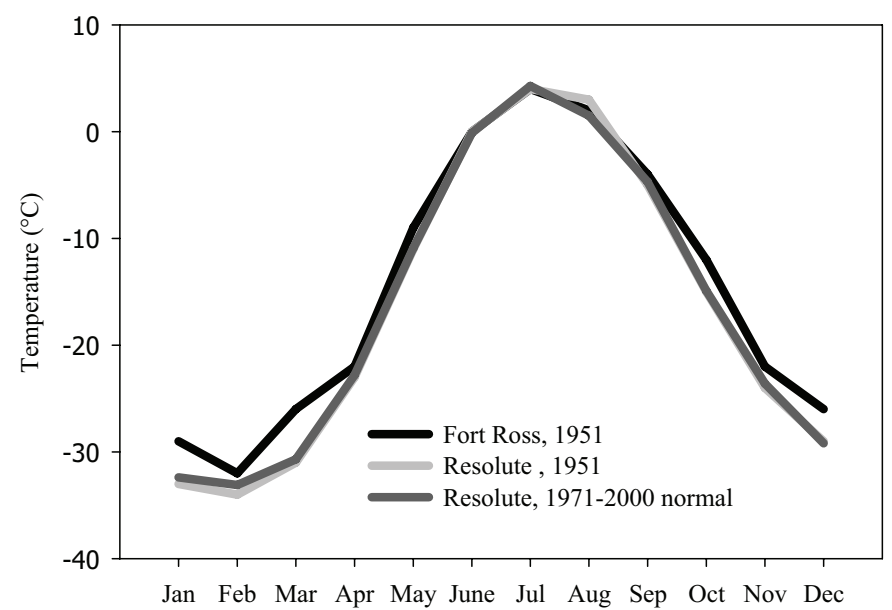

FIG. 2. Average monthly mean temperatures from Fort Ross (1951, source: Dyke, 1983) and Resolute Bay. Also plotted are the 30-year normals (1971 to 2001) from Resolute Bay. (Source: Environment Canada, 2008.)

(Fig. 1). Comparison of monthly temperature and precipitation values for Fort Ross (southern Somerset Island) and Resolute Bay reveals much similarity between the two islands (Fig. 2). The weather at these two sites can be considered to have cold, dry winters and brief, cool, damp summers (Dyke, 1983). At Resolute Bay, the mean annual air temperature is $-16.4^{\circ} \mathrm{C}$, with summer temperatures typically reaching between $-0.1^{\circ} \mathrm{C}$ and $4.3^{\circ} \mathrm{C}$. The 30 -year Resolute normals (1971-2000) for precipitation indicate $50.3 \mathrm{~mm}$ of rainfall with a mean total annual precipitation of $150 \mathrm{~mm}$ (Environment Canada, 2008). This value is likely higher in the surrounding landscape owing to gauge undercatch and the siting of the weather station at a low elevation near the coast (Woo and Ohmura, 1997). Fort Ross precipitation data (not shown here) are comparable (Dyke, 1983).

This study focused on four ponds that possessed the most detailed information over the two study periods (Table 1). To justify the selection of the sites, field reconnaissance in 2004 allowed an initial assessment of pond variability in area, water quality, frost, and water table for about 75 ponds situated in the different geomorphic zones contained within this wetland (Young and Abnizova, 2008). The study ponds originally selected were named Moraine, Coastal, and Bedrock after the three broad geomorphic areas they represent (Fig. 3). The moraine zone couples an upland plateau with a lowland area. The lowland zone receives water throughout most of the snow-free season via a stream that collects meltwater and rainwater from an upland catchment, sustaining numerous ponds through its discharge. Because the upland stream catchment zone is so important to this lowlying wetland system, a pond in that zone was selected as the fourth study site and called the Plateau site. Frost cracks are common in the coastal area, often running from the hillslope into the coastal zone and ranging in size from minor undulations to deep depressions. A frost crack situated downslope from the Coastal pond was studied to assess its role in delivering water to the pond or conversely its ability to drain water from the pond.
The topography of the Moraine pond catchment is highly variable (Fig. 4, Table 1). An uneven pond bottom is enhanced by a thick organic substrate and a community of sedges, Carex aquatilis, near the banks. The pond substrate is mainly fines with a high proportion of organic matter (Young and Abnizova, 2008). The Plateau pond has a relatively flat topography with a mainly sandy substrate and diatom and blue-green algae (periphytic cyanobacteria) communities. The bathymetry of the Coastal pond highlights a low degree of topographic variability with a maximum change of depth of $0.30 \mathrm{~m}$ (Fig. 4, Table 1). The pond bottom is mainly sand $(80 \%)$ with very low organic matter $(<5 \pm 1 \%)$ (Young and Abnizova, 2008). A frost crack $1-2 \mathrm{~m}$ wide (not shown) is located $9 \mathrm{~m}$ downslope from the pond center and runs east-west. The substrate of the Bedrock pond is composed of large calcareous rocks and pebbles, while the pond's catchment is devoid of vegetation and consists largely of gravel beach ridges. The rocky pond bottom is covered with a thin organic layer composed of detrital blue-green algal filaments. These filaments often form thin mats and are typical in other High Arctic rocky ponds (Nogrady and Smol, 1989). The topography of the pond catchment highlights large local differences in elevation. The steep slope south of the pond has a 1.1 gradient.

In 2005, the study period was late May to early August and generally covered the pre-snowmelt and freeze-back periods. In 2006, an unexpected emergency in late July shortened our field season.

\section{THEORY AND METHODS}

A water balance framework after Woo et al. (1981) was used to assess the hydrologic dynamics of ponds and determine their sustainability in a polar desert climatic setting. Here,

$$
\mathrm{dS} / \mathrm{dt}=\mathrm{P}-\mathrm{E} \pm \mathrm{Q}
$$

where $\mathrm{dS} / \mathrm{dt}$ is the storage term used to describe the change in the volume of water in the ponds, $\mathrm{P}$ is precipitation input obtained by summing snow and rain, $\mathrm{E}$ is evaporation output, and Q is surface and subsurface inflow or outflow to the pond. The water balance of each pond was assumed to be dependent on the surface and subsurface water supplies and losses from the pond's basin.

\section{Precipitation (Snow and Rainfall)}

At the beginning of the field season, a snow survey at each pond site was conducted to determine the amount of snow water equivalent (SWE) contained in the ponds at the end of winter. SWE is determined by the formula

$$
\operatorname{SWE}(\mathrm{mm})=\mathrm{d}\left(\rho_{\mathrm{s}} / \rho_{\mathrm{w}}\right)
$$




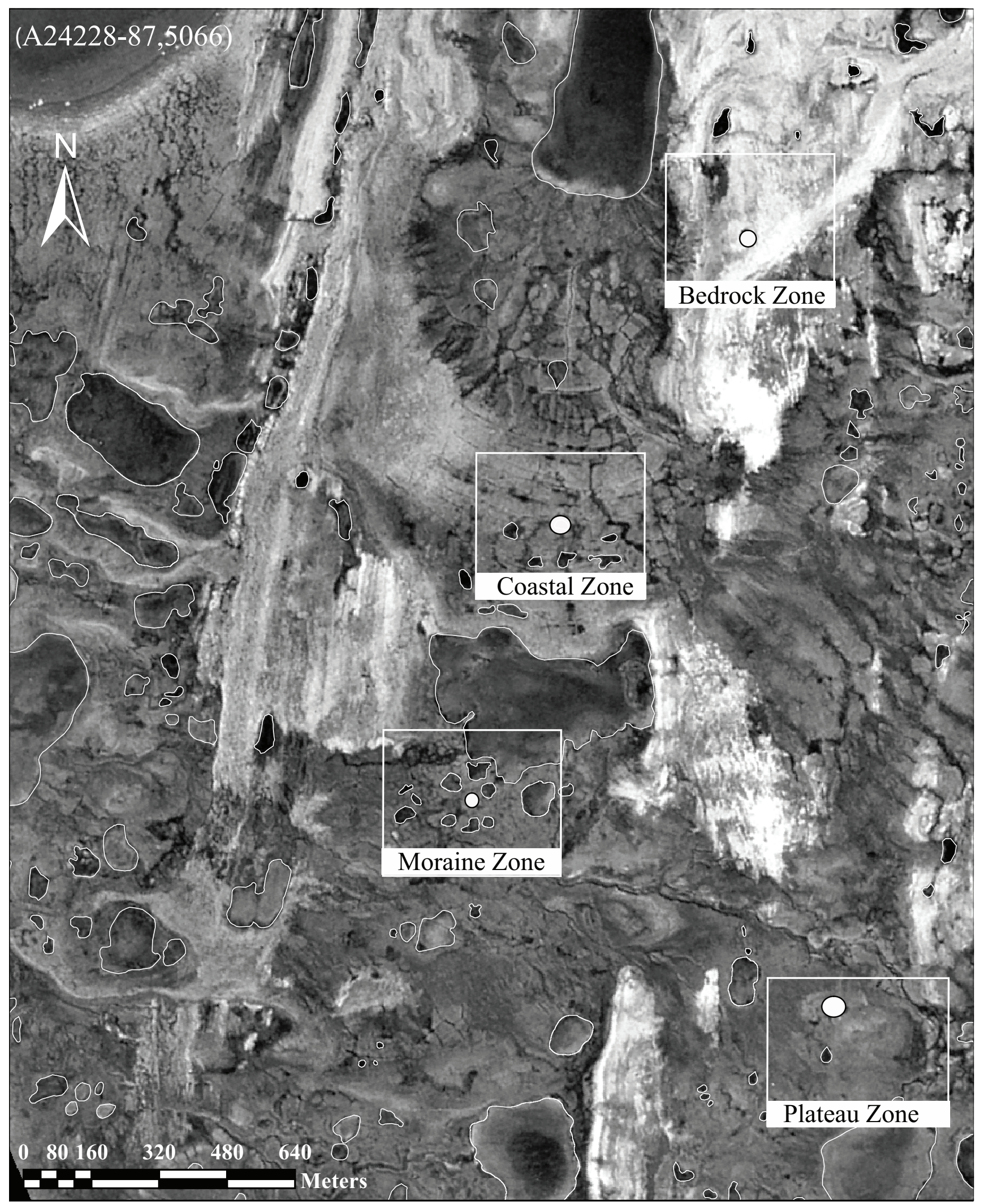

FIG. 3. Aerial photograph of the study area, showing general terrain types and study ponds (white circles) described in this manuscript. Flight line and photo number are indicated in the top lefthand corner. Photo (dated 11 August 1975) courtesy of Natural Resources Canada. 
TABLE 1. Location and description of study ponds.

\begin{tabular}{|c|c|c|c|c|c|}
\hline $\begin{array}{l}\text { Type } \\
\text { (Location) }\end{array}$ & $\begin{array}{l}\text { Surface Area } \\
\qquad\left(\mathrm{m}^{2}\right)\end{array}$ & $\begin{array}{l}\text { Average Depth } \\
\quad(\mathrm{m})\end{array}$ & Soil Type/Texture & Organics & $\begin{array}{l}\text { Frost Table } \\
\operatorname{Depth}^{2}(\mathrm{~mm})\end{array}$ \\
\hline $\begin{array}{l}\text { Moraine } \\
\quad \text { (lowland) }\end{array}$ & 149 & 0.30 & $\begin{array}{l}\text { sandy silt consisting of fine } \\
\text { sand and silt }(80 \% \text { and } 20 \%)\end{array}$ & $\begin{array}{l}\text { organic layer }<140 \mathrm{~mm} \text { thick, mosses, lichens, vascular } \\
\text { plants; Cassiope tetragona, Dryas integrifolia, Salix arctica }\end{array}$ & 498 \\
\hline $\begin{array}{l}\text { Plateau } \\
\quad \text { (upland) }\end{array}$ & 1074 & 0.20 & sand & $\begin{array}{l}\text { organic layer }<50 \mathrm{~mm} \text { thick, sporadic mosses, lichens, } \\
\text { some vascular plants }\end{array}$ & 810 \\
\hline $\begin{array}{l}\text { Coastal } \\
\quad \text { (lowland) }\end{array}$ & 1386 & 0.20 & coarse sand & organic layer $<10 \mathrm{~mm}$ thick, sporadic mosses and lichens & 827 \\
\hline $\begin{array}{l}\text { Bedrock } \\
\quad \text { (upland) }\end{array}$ & 646 & 0.25 & rocks and pebbles & no organic layer & 894 \\
\hline
\end{tabular}

${ }^{1}$ Average water depth in the middle of the pond in late June 2005.

${ }^{2}$ Frost table depth in the middle of the pond on 12 August 2005.
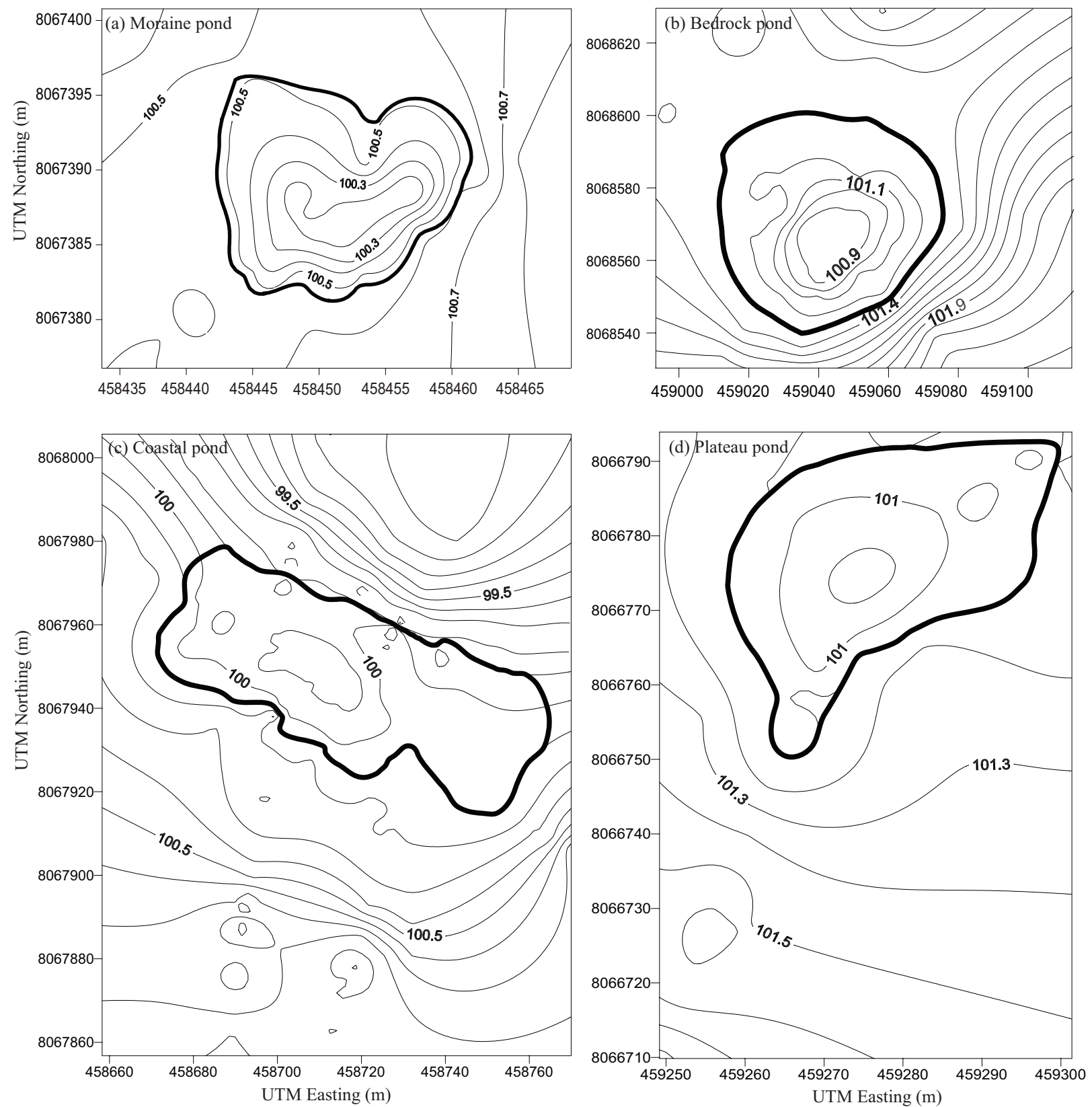

FIG. 4. Topographic diagrams of study ponds and adjacent catchments: (a) Moraine; (b) Bedrock; (c) Coastal; and (d) Plateau. Contour interval is $0.1 \mathrm{~m}$. Elevations are in meters above an arbitrary datum. The thick line outlines each pond area at its greatest flooded extent. 
where $d$ is measured snow depth $(\mathrm{mm}), \mathrm{p}_{\mathrm{s}}$ is snow density $\left(\mathrm{kg} / \mathrm{m}^{3}\right)$, and $\mathrm{p}_{\mathrm{w}}$ is the density of water $\left(1000 \mathrm{~kg} / \mathrm{m}^{3}\right)$. Data collection followed the methodology described by Woo (1997). The series of transects that was laid out encompassed both the pond and its catchment. Along each transect, depth measurements were made at 1 to $2 \mathrm{~m}$ intervals depending on the size of the pond catchment. Geographical coordinates of starting and ending points of transects were recorded with a Garmin GPS12XL $( \pm 5 \mathrm{~m})$. Snow depth measurements were obtained by inserting a metric ruler $( \pm 5 \mathrm{~mm})$ into the snowpack. Depending on the length of transects, 1 to 3 snow density cores were obtained (at beginning, middle, and end of each transect) with a Meteorological Service of Canada (MSC) snow corer.

The onset and process of snowmelt were measured directly using snow ablation lines installed to quantify daily lowering of the snow surface, which was converted into water equivalent units using the surface snow density (Heron and Woo, 1978). In this environment, patches of late-lying snow typically linger after the snowmelt season. Elevated plateau areas tend to be windswept in this treeless environment, while much snow can collect in depressions and lee of slopes, giving rise to late-lying or perennial snowbeds (Young and Lewkowicz, 1990). Previously, Young and Woo (2003) and Woo and Young (2003) demonstrated that meltwater from these features can be effective in sustaining water levels in patchy wetlands downslope. A detailed snow survey was conducted on one late-lying snowbed located to the west of the Moraine study pond. Snowbed recession was measured every 4 to $5 \mathrm{~m}$ along 11 transects twice a week, and photographs of retreat were also obtained.

Summer precipitation was continuously measured with a series of recording and manual rain gauges. Three electronic tipping-bucket rain gauges were located in the study area: one near the automatic weather station (AWS) in the Moraine zone, one near base camp on the upper Plateau, and one at the Bedrock site. Manual rain gauges were also deployed near each study pond to provide a check against recorded estimates. Manual rain gauges were checked every other day and following rainfall. The rainfall record is used to estimate the amount of water that is available to the pond and its catchment.

\section{Evaporation}

Evaporation rates (vertical water loss) were calculated with the Priestley-Taylor (PT) method. This approach has been successfully employed in other northern wetland studies (e.g., Mendez et al., 1998; Woo and Guan, 2006) and it ranks high in accuracy in relation to other approaches (Rosenberry et al., 2004). Here, it is defined as,

$$
\mathrm{E}_{\mathrm{PT}}=\alpha_{\mathrm{p}}(\Delta /(\Delta+\gamma))\left(\mathrm{Q}^{*}-\mathrm{Q}_{\mathrm{G}}\right)
$$

where $E_{\mathrm{PT}}$ is the latent heat flux in $\mathrm{MJ} / \mathrm{m}^{2}, \alpha_{\mathrm{p}}$ is set at 1.26 , which is generally considered appropriate for saturated surfaces (e.g., Stewart and Rouse, 1977), $\Delta$ is the slope of the temperature-saturated vapour pressure curve in $\mathrm{Pa} /{ }^{\circ} \mathrm{C}$, and $\gamma$ is the psychrometric constant $66 \mathrm{~Pa} /{ }^{\circ} \mathrm{C}$. Net radiation, $\mathrm{Q}^{*}\left(\mathrm{MJ} / \mathrm{m}^{2}\right)$ was measured over open water and saturated ground. $Q_{G}\left(\mathrm{MJ} / \mathrm{m}^{2}\right)$ refers to the ground heat flux or water heat flux $\left(\mathrm{Q}_{\mathrm{WH}}\right)$. The $\mathrm{Q}_{\mathrm{WH}}$ was computed using the following equation (Woo and Guan, 2006):

$$
\mathrm{Q}_{\mathrm{WH}}=\mathrm{cz}_{\mathrm{w}}\left(\mathrm{dT}_{\mathrm{w}} / \mathrm{dt}\right)
$$

where $\mathrm{dT}_{\mathrm{w}} / \mathrm{dt}$ is daily change in pond water temperature (in ${ }^{\circ} \mathrm{C}$ ) integrated over the water depth $\mathrm{z}_{\mathrm{w}}$ (in $\mathrm{m}$ ) of the pond. and $\mathrm{c}$ is the volumetric heat capacity of water in $\mathrm{J} / \mathrm{m}^{3}{ }^{\circ} \mathrm{C}$.

Daily evaporation (E), expressed in water depth units $(\mathrm{mm})$ was obtained by converting Equation 3 by the following:

$$
\mathrm{E}=\mathrm{E}_{\mathrm{PT}} /\left(\rho_{\mathrm{w}} \lambda_{\mathrm{v}}\right)
$$

where $\lambda_{v}$ is the latent heat of vaporization in $\mathrm{J} / \mathrm{kg}$, and $\mathrm{p}_{\mathrm{w}}$ is the density of water $\left(1000 \mathrm{~kg} / \mathrm{m}^{3}\right)$.

In order to consider changing surface area of open water in the pond, evaporation was expressed in volumetric units, following Woo and Guan (2006):

$$
\mathrm{E}=\mathrm{E}_{\mathrm{w}} \mathrm{A}_{\mathrm{w}}
$$

where $E$ is total evaporation from the pond $\left(\mathrm{m}^{3}\right), \mathrm{E}_{\mathrm{W}}$ is evaporation from water $(\mathrm{m})$, and $\mathrm{A}_{\mathrm{W}}$ is the pond's respective surface area $\left(\mathrm{m}^{2}\right)$. The changes in pond surface area were obtained by monitoring the boundary of each pond for shrinkage or expansion. As the thaw season commenced, markers were placed at the initial pond boundaries, and twice weekly, the distances from each marker to the pond edge and the center well were measured. ArcView GIS 3.2, Golden Software Surfer 7.0 together with topographic survey data obtained from a Lecia GPS Total Survey station $( \pm 0.5 \mathrm{~mm})$ allowed mapping of pond locations, areal coverage, catchment size changes and water linkages at various scales.

Climate data for evaporation estimates - net radiation $\left(\mathrm{Q}^{*}\right)$, air temperature $(\mathrm{T})$, ground heat flux $\left(\mathrm{Q}_{\mathrm{G}}\right)$, and pond water temperature (TW) - were provided by a permanent automatic weather station (AWS) and a roving automatic weather station (RWS). The AWS was centrally located in the Moraine zone, about $4 \mathrm{~km}$ inland. Its close proximity to base camp ensured that instrumentation could be checked frequently. A smaller roving weather station allowed climatic conditions at all study ponds to be compared to the centrally located AWS and to each other. The roving station was placed for two consecutive days over each pond surface on two separate occasions in 2005 but only once in 2006. The climate data obtained from the RWS made it possible to estimate differences in net radiation for the pond sites. Regression analysis between diurnal net radiation at each study pond and $\mathrm{Q}^{*}$ measured in $\mathrm{W} / \mathrm{m}^{2}$ at the AWS allowed for continuous $\mathrm{Q}^{*}$ estimates and provided an approach to 
examining similarities and differences. The sensible heat flux $\left(\mathrm{Q}_{\mathrm{H}}\right)$ was determined using the bulk transfer approach during snowmelt (e.g., Price and Dunne, 1976) and was calculated as a residual during the post-snowmelt season. The types of instrumentation employed in the study and their degrees of uncertainty are described in Table 2.

\section{Surface Lateral Fluxes}

To qualify and quantify lateral water inputs and losses from pond systems, several landscape features were examined. Pond connectivity to its catchment can be assessed using active layer soil moisture in the transition zone. Saturation overland flow occurs when active layer moisture storage is at its maximal capacity. Such conditions can be equivalent to a zero storage deficit. According to Marsh and Woo (1977), high soil moisture conditions of catchment soils and high water tables can be beneficial in conducting rainwaters into a pond via surface and subsurface inflows. The storage deficit (SD, $\mathrm{mm}$ ) of a typical tundra soil can be calculated using the following formula:

$$
\mathrm{S}_{\mathrm{D}}=\Sigma \mathrm{n}(1-\theta) \mathrm{z}
$$

where $\mathrm{n}$ is the porosity of the soil, and $\theta$ is the volumetric soil moisture (fraction), and $\mathrm{z}$ is the thickness $(\mathrm{mm})$ of the soil layer (Glenn and Woo, 1997). In 2005, extensive soil moisture measurements were made around the pond and near wells located in pond transition zones using a Theta Probe. Here, transition zones are defined as catchment zones located between the areas of open water and upland inlets and lowland outlets. Each week, near-surface gravimetric soil moisture samples (ca. $250 \mathrm{~cm}^{3}, \mathrm{n}=106$ ) were obtained, weighed, and air-dried in the field. Later these samples were oven-dried at the Biogeochemistry lab at York University, following the approach by Black (1965). The soil moisture samples provided a check on Theta probe soil moisture measurements $\left(\mathrm{R}^{2}=0.83, p<0.05\right)$. No Theta probe was available in 2006, so only a few gravimetric soil moisture samples were obtained from each site over the season ( $\mathrm{n}=12$, data not shown here) and later converted to volumetric units using bulk density estimates.

Stream discharge flowing from the plateau zone into the low-lying moraine area was monitored in both 2005 and 2006. A gauging station was established at the entrance to the low-lying wetland zone, and a water level recorder was set up to continuously measure stage in 2006 . No water level recorder was available in 2005, so regular spot measurements were obtained during high and low flow periods. Stage measurements $(\mathrm{H}, \mathrm{cm})$, taken two to three times per day during snowmelt, and less frequently during the post-snowmelt period, together with regular current metering, established reliable stage-discharge relationships. Here, inflow (L/s) was $\mathrm{Q}=2.86^{-2} \mathrm{H}^{2.60},\left(\mathrm{n}=14, \mathrm{R}^{2}=0.92, p<0.05\right)$ in 2005 and was $\mathrm{Q}=9.25 \mathrm{H}^{1.43}\left(\mathrm{n}=13, \mathrm{R}^{2}=0.92, p<0.05\right)$ in 2006 .

The Coastal site contains numerous frost cracks running both horizontally and perpendicular to the coast, which are triggered by thermal contraction of the ground associated with the isostatic uplift process. These frost cracks are potential hydrological pathways for moving water to and from the ponds. To estimate the hydrological role played by frost cracks in pond sustainability, one frost crack downslope from the medium pond in the Coastal zone was monitored in both years $(0.3-0.5 \mathrm{~m}$ depth and $1-2 \mathrm{~m}$ width). The monitoring consisted primarily of regular measurements of water and frost tables.

\section{Groundwater Flow}

Darcy's law (e.g., Young et al., 1997) was used to determine groundwater flow into and out of the ponds. Groundwater flow $\left(\mathrm{Q}_{\mathrm{S}}\right.$, in $\mathrm{m}^{2} / \mathrm{d}$ per unit width) was determined using:

$$
\mathrm{Q}_{\mathrm{S}}=\mathrm{k}_{\mathrm{s}} \mathrm{d}_{\mathrm{s}}(\mathrm{dh} / \mathrm{dx})
$$

where $\mathrm{k}_{\mathrm{s}}$ is the saturated hydraulic conductivity $(\mathrm{m} / \mathrm{d}), \mathrm{d}_{\mathrm{s}}$ is the thickness of the saturated zone (m) obtained daily as the elevation difference between the frost and the water table positions, and $\mathrm{dh} / \mathrm{dx}$ is the hydraulic gradient estimated by the elevation of the water table in adjacent wells (Young et al., 1997). Estimates of $k_{s}$ were performed using a bailing test described by Luthin (1966). In total, at least one measurement was made at each pond site at the end of the snowmelt period when soils were saturated.

A series of perforated and screened water wells had been installed at each study pond the previous year (2004), to the maximum depth of thaw. One well was placed at the centre of each pond. Other wells, usually four or more, were placed in the transition zone about one meter beyond the open water of the pond edge. Water level in wells was monitored frequently during the melt and post-melt periods with water level sensors $( \pm 5 \mathrm{~mm})$. A water level recorder placed at the centre of each study pond and connected to a Campbell Scientific data-logger allowed pond water table fluctuations to be monitored on a continuous basis $( \pm 5 \mathrm{~mm}$ ) (Table 2). Ground thaw was estimated near all water wells either daily or twice weekly. A metal rod was inserted into the ground until frozen ground was reached. Since the truncated field season in 2006 precluded direct measurements, late ground thaw in that year was estimated using an empirical relationship described by Woo and Steer (1983). Here,

$$
\mathrm{Z}(\mathrm{t})=\beta \sqrt{ } \square \mathrm{t}
$$

where $\mathrm{Z}(\mathrm{t})$ is depth of thaw $(\mathrm{m})$ at time $\mathrm{t}$, and $\mathrm{t}$ is the time in days since the initiation of thaw. $\beta$ is a coefficient that varies with soil material. All elevations were obtained with a Lecia GPS Total Survey Station in late July 2005.

\section{Water Storage}

As mentioned above, the dynamics of pond water levels were estimated on a diurnal and seasonal basis using 
TABLE 2. Climatologic and hydrologic instrumentation.

\begin{tabular}{|c|c|c|c|}
\hline Variable/Parameter & Instrument $^{1}$ & Location and Elevation & Accuracy \\
\hline Net Radiation & $\begin{array}{l}\text { Net Radiometer (Kipp and Zonen) } \\
\text { Net Radiometer (Middleton) }\end{array}$ & $\begin{array}{l}\operatorname{RWS}^{2}(1 \mathrm{~m}) \\
\operatorname{AWS}^{3}(1 \mathrm{~m})\end{array}$ & $\begin{array}{l}>_{ \pm} 1 \% \text { or } 0.01 \mathrm{MJ} / \mathrm{m}^{2} \mathrm{~h} \\
> \pm 1 \% \text { or } 0.01 \mathrm{MJ} / \mathrm{m}^{2} \mathrm{~h}\end{array}$ \\
\hline Solar Radiation & $\begin{array}{l}\text { Pyranometer CMP21 (Kipp and Zonen) } \\
\text { Pyranometer LI-200 (LI-COR Biosciences) }\end{array}$ & $\begin{array}{l}\text { AWS (1 m) } \\
\text { RWS (1 m) }\end{array}$ & $\begin{array}{l}> \pm 1 \% \text { or } 0.01 \mathrm{MJ} / \mathrm{m}^{2} \mathrm{~h} \\
> \pm 5 \% \text { or } 0.05 \mathrm{MJ} / \mathrm{m}^{2} \mathrm{~h}\end{array}$ \\
\hline Ground Heat Flux & Heat Flux Plate (Middleton) & AWS and RWS (-0.05 m) & $\pm 3 \%$ \\
\hline Wind Speed & $\begin{array}{l}\text { R.M. Young } 05103 \text { Wind Monitor } \\
\text { Anemometer } 7911 \text { (Davis Instruments) }\end{array}$ & $\begin{array}{l}\text { AWS }(1.5 \mathrm{~m}) \\
\text { AWS }(1.5 \mathrm{~m})\end{array}$ & $\begin{array}{l}( \pm 0.2 \mathrm{~m} / \mathrm{s}) \\
> \pm 5 \%\end{array}$ \\
\hline Wind Direction & $\begin{array}{l}\text { R.M. Young } 05103 \text { Wind Monitor } \\
\text { Anemometer } 7911 \text { (Davis Instruments) }\end{array}$ & $\begin{array}{l}\text { RWS }(1.5 \mathrm{~m}) \\
\operatorname{RWS}(1.5 \mathrm{~m})\end{array}$ & $\begin{array}{l} \pm 3^{\circ} \\
\pm 7^{\circ}\end{array}$ \\
\hline Air Temperature and Relative Humidity & CSI Probe & AWS (1 m) & $\pm 2^{\circ} \mathrm{C}$ and $5 \%$ respectively \\
\hline Air Temperature & StowAway TidbiT & RWS (1 m) & $\pm 0.2^{\circ} \mathrm{C}$ \\
\hline Water and Snow Temperatures & $\begin{array}{l}\text { StowAway TidbiT } \\
\text { Thermocouples, Type T, Copper Constantan }\end{array}$ & $\begin{array}{l}\text { Pond and snowpack } \\
\text { Soil surface, pond surface }\end{array}$ & $\begin{array}{l} \pm 0.2^{\circ} \mathrm{C} \\
\pm 0.1^{\circ} \mathrm{C}\end{array}$ \\
\hline Precipitation & RG600 Tipping Bucket Rain gauge, 8" & Camp Site, AWS and Bedrock Site & $\pm 0.25 \mathrm{~mm}$ \\
\hline Water Table & $\begin{array}{l}\text { Water Table Recorders } \\
\text { Groundwater Well and Tape Measure }\end{array}$ & $\begin{array}{l}\text { Continuous } \\
\text { Daily }\end{array}$ & $\begin{array}{l} \pm 0.1 \mathrm{~mm} \\
\pm 0.1 \mathrm{~mm}\end{array}$ \\
\hline Soil Moisture & $\begin{array}{l}\text { ThetaProbe Soil Moisture Sensor-ML2x (Delta T) } \\
\text { ECHO probe model EC-10 (ECH2O) }\end{array}$ & $\begin{array}{l}\text { Point measurements } \\
\text { Medium pond's transition soils }\end{array}$ & $\begin{array}{l} \pm 1 \% \\
\pm 3 \%\end{array}$ \\
\hline Elevation & Total Survey Station & Topography at each site & $\pm 1 \%$ \\
\hline Surface Flow Velocity & $\begin{array}{l}\text { OTT C2 (OTT) } \\
\text { Pygmy Meter }\end{array}$ & Input and output stream locations & $\begin{array}{l} \pm 1 \% \\
\pm 2 \%\end{array}$ \\
\hline
\end{tabular}

${ }^{1}$ Instruments calibrated before going into the field.

${ }^{2}$ RWS $=$ Roving Weather Station.

${ }^{3}$ AWS $=$ Automated Weather Station.

continuously monitored water level recorders connected to Campbell Scientific data loggers (see Table 2). During the 2005 and 2006 summer seasons, manual water level measurements were collected twice weekly at the center well and near the water level recorder. These latter measurements were used to verify the reliability of the continuous stage measurements. Shrinkage and expansion of pond surface area, and hence water storage, were monitored weekly.

\section{RESULTS AND DISCUSSION}

\section{Climatic Setting}

Temperature and precipitation records in 2005 and 2006 indicate that this area experiences a polar desert climate much like that of Resolute Bay and unlike that of Eureka, which has a polar oasis type of regime (Woo and Young, 1997) (Fig. 5, Table 3). Mean summer temperatures at Creswell Bay were slightly warmer than at Resolute Bay in both years $\left(3.7^{\circ} \mathrm{C}\right.$ vs. $2.8^{\circ} \mathrm{C}$ in $2005 ; 2.7^{\circ} \mathrm{C}$ vs. $1.5^{\circ} \mathrm{C}$ in 2006$)$. Summer precipitation at Creswell Bay was comparable to that of Resolute Bay. In 2005, total rainfall was $46.6 \mathrm{~mm}$ vs. $50.8 \mathrm{~mm}$ at Resolute Bay. In 2006, rainfall was slightly higher, $68.2 \mathrm{~mm}$ vs. $56.4 \mathrm{~mm}$.

Spring and summer climatic conditions in Arctic environments can vary from year to year (e.g., Thompson, 1967; Rydén, 1977). In 2005, temperatures rose rapidly and exceeded $0^{\circ} \mathrm{C}$ by 8 June. In 2006, air temperatures initially jumped above $0^{\circ} \mathrm{C}$ on 11 June but fell back to $-5^{\circ} \mathrm{C}$ during a period of cloudy conditions when incoming radiation levels were dampened. Positive air temperatures did not occur until 16 June. Warmest temperatures occurred in 2006, reaching $13^{\circ} \mathrm{C}$ on about 11 to 17 July (Fig. 5). This rise corresponded to a high-pressure system covering most of the Arctic islands.

In both years, average monthly values of relative humidity exceeded $80 \%$, indicating a humid environment, but extended episodes of drying did occur in early August 2005 and for a few weeks in July 2006. Figure 5 shows that wind speed was moderate in both years: monthly averages ranged from 3.3 to $4.0 \mathrm{~m} / \mathrm{s}$, with an event gusting up to $8 \mathrm{~m} / \mathrm{s}$ in 2006. Prevailing winds were from the west, but winds from both north and south were frequent (data not shown here).

The frequency and duration of precipitation events are important in the water budget of high-latitude freshwater environments as precipitation is often the only source of water to ponds and other ecosystems during the post-snowmelt season (Kane and Carlson, 1973). On occasion, latesummer rains can recharge ponds to snowmelt levels (Woo and Guan, 2006). The precipitation pattern of 2005 was typical of other polar desert environments: the frequency of rainfall increased toward late July, and August was the wettest month of the year (Woo et al., 1981). Precipitation events in 2006 occurred mainly during snowmelt and in the early thaw season towards the end of June and were of a longer duration than those in 2005. In summary, 2006 was slightly cooler and wetter than 2005.

Air temperatures at the ponds showed higher values at the Bedrock and Coastal sites than at the Moraine site 

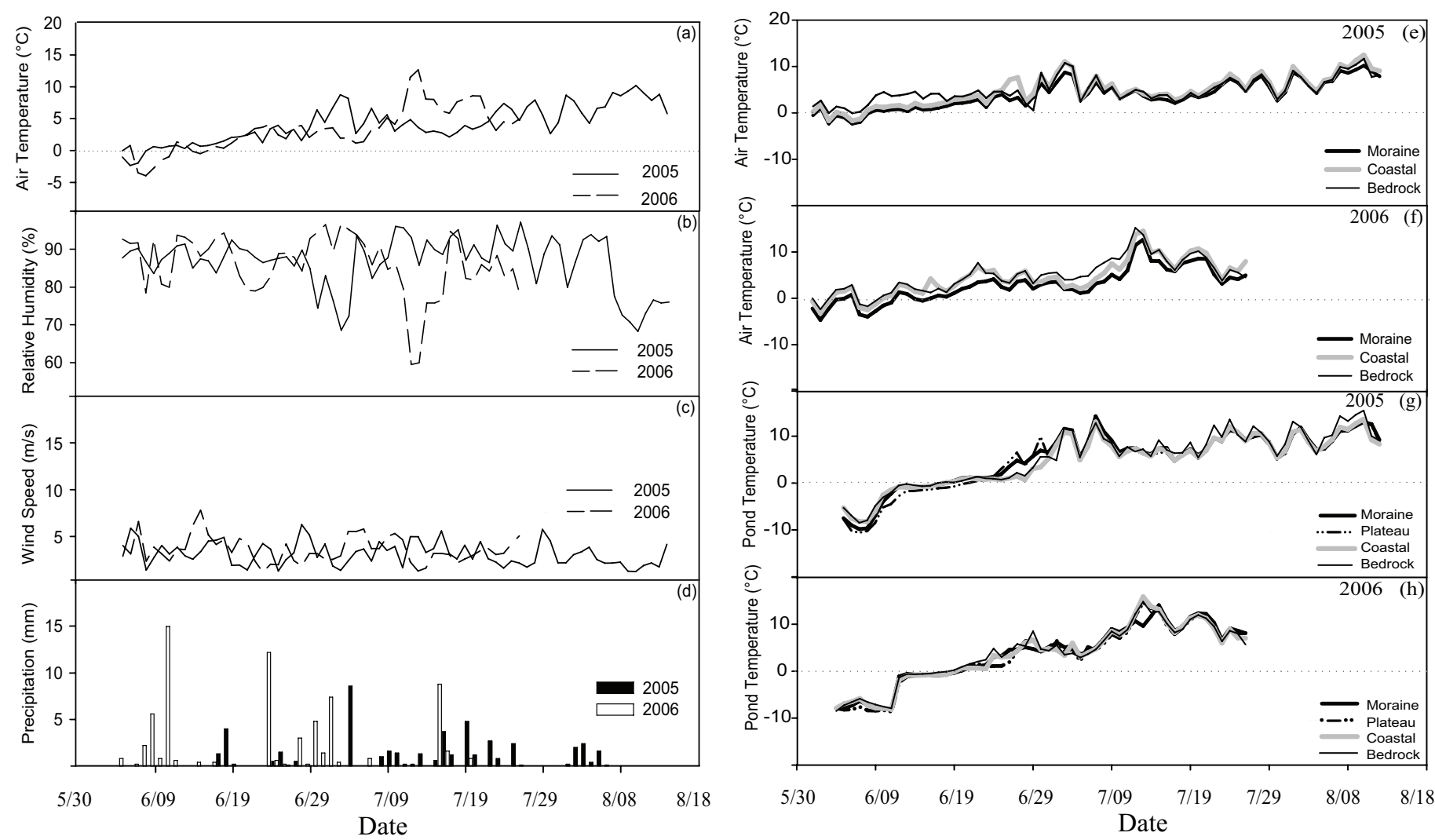

FIG. 5. Seasonal patterns (2005 and 2006) of (a) daily air temperature at the main Automatic Weather Station (AWS) at Creswell Bay, (b) mean daily relative humidity (\%), (c) mean daily wind speed (m/s), (d) daily total precipitation, (e and f) air temperature at the pond sites, and ( $\mathrm{g}$ and $\mathrm{h}$ ) pond water temperatures.

TABLE 3. June, July and August climatic data from the study site and major government weather stations.

\begin{tabular}{|c|c|c|c|c|c|c|}
\hline \multirow[b]{2}{*}{ Site } & \multicolumn{2}{|c|}{ Mean Temperature $\left({ }^{\circ} \mathrm{C}\right)$} & \multicolumn{2}{|c|}{ Precipitation (mm) } & \multicolumn{2}{|c|}{ Degree-days above $0^{\circ} \mathrm{C}$} \\
\hline & 2005 & 2006 & 2005 & 2006 & 2005 & 2006 \\
\hline Creswell Bay $\left(72^{\circ} 43^{\prime} \mathrm{N}, 94^{\circ} 15^{\prime} \mathrm{W}\right)$ & $3.67(2.80)^{2}$ & $2.82^{3}$ & $46.6(39.8)$ & $68.2^{3}$ & $338(157)$ & $158^{3}$ \\
\hline Resolute Bay $\left(74^{\circ} 43^{\prime} \mathrm{N}, 94^{\circ} 59^{\prime} \mathrm{W}\right)^{1}$ & $2.71(2.07)$ & $2.77(1.48)$ & $50.8(19.6)$ & $69.2(56.4)$ & $249(116)$ & $255(83)$ \\
\hline Eureka $\left(79^{\circ} 58^{\prime} \mathrm{N}, 85^{\circ} 55^{\prime} \mathrm{W}\right)^{1}$ & $5.66(5.90)$ & $3.93(3.94)$ & $28.8(18.8)$ & $65.8(33.8)$ & $521(328)$ & $362(226)$ \\
\hline
\end{tabular}

${ }^{1}$ Weather data from Environment Canada (2008).

${ }^{2}$ Data in parentheses are calculations from 1 June to 26 July for comparison with shorter 2006 period at Creswell Bay.

${ }^{3}$ Data collected at Creswell Bay during shorter field season from 1 June to 26 July 2006.

(Fig. $5 \mathrm{e}-\mathrm{f}$ ), reaching a maximum value of $14^{\circ} \mathrm{C}$ on 12 July 2006. Figure $5 \mathrm{~g}-\mathrm{h}$ shows that the Bedrock pond had the highest average daily water temperature throughout 2005 , reaching a maximum $\left(15.5^{\circ} \mathrm{C}\right)$ at the end of the season, while the Moraine pond remained the coolest. In 2006, the Bedrock pond warmed quickly to $9^{\circ} \mathrm{C}$, while other ponds averaged $5^{\circ} \mathrm{C}$ (Fig. $5 \mathrm{~h}$ ). The Moraine pond was slower to melt out and temperatures were subsequently lower. As the thaw season progressed, daily average pond temperatures at all sites became similar, but the Bedrock and Coastal ponds remained warmer than the Moraine and Plateau ponds.

Surface energy fluxes for the main AWS are considered here because they play a key role in a suite of hydrologic processes such as snowmelt, evaporation, and ground thaw (Fig. 6). The main AWS, centrally located in the wetland, is situated in a wet meadow zone. In comparison to the other fluxes, net radiation dominated, and this situation can be considered typical of other Arctic environments (Smithson et al., 2002). Net radiation was negative before initiation of snowmelt (up to ca. $-3.0 \mathrm{MJ} / \mathrm{m}^{2} \mathrm{~d}$ in early June in both years), but later on it reached daily highs of $14 \mathrm{MJ} / \mathrm{m}^{2} \mathrm{~d}$ on 8 July 2005 and $19 \mathrm{MJ} / \mathrm{m}^{2} \mathrm{~d}$ on 22 June 2006 . The ground heat flux $\left(\mathrm{Q}_{\mathrm{G}}\right)$ is negligible during snowmelt (Prowse and Owens, 1982) and therefore was not measured until the ground began to thaw. In the post snowmelt period, $\mathrm{Q}_{\mathrm{G}}$ values increased and remained positive, reaching $4 \mathrm{MJ} / \mathrm{m}^{2} \mathrm{~d}$ on 3 July 2005 and $3 \mathrm{MJ} / \mathrm{m}^{2} \mathrm{~d}$ on 13 July 2006. Overall, $Q_{G}$ averaged $1.53 \mathrm{MJ} / \mathrm{m}^{2} \mathrm{~d}$ and consumed about $29 \%$ of Q* in 2005 and $20 \%$ in 2006 . This pattern is comparable to findings of other studies (e.g., Halliwell and Rouse, 1987; Harazono et al., 1998). In the study by Boike et al. (2008), $29 \%$ of Q* was partitioned into ground heat flux during a warm 


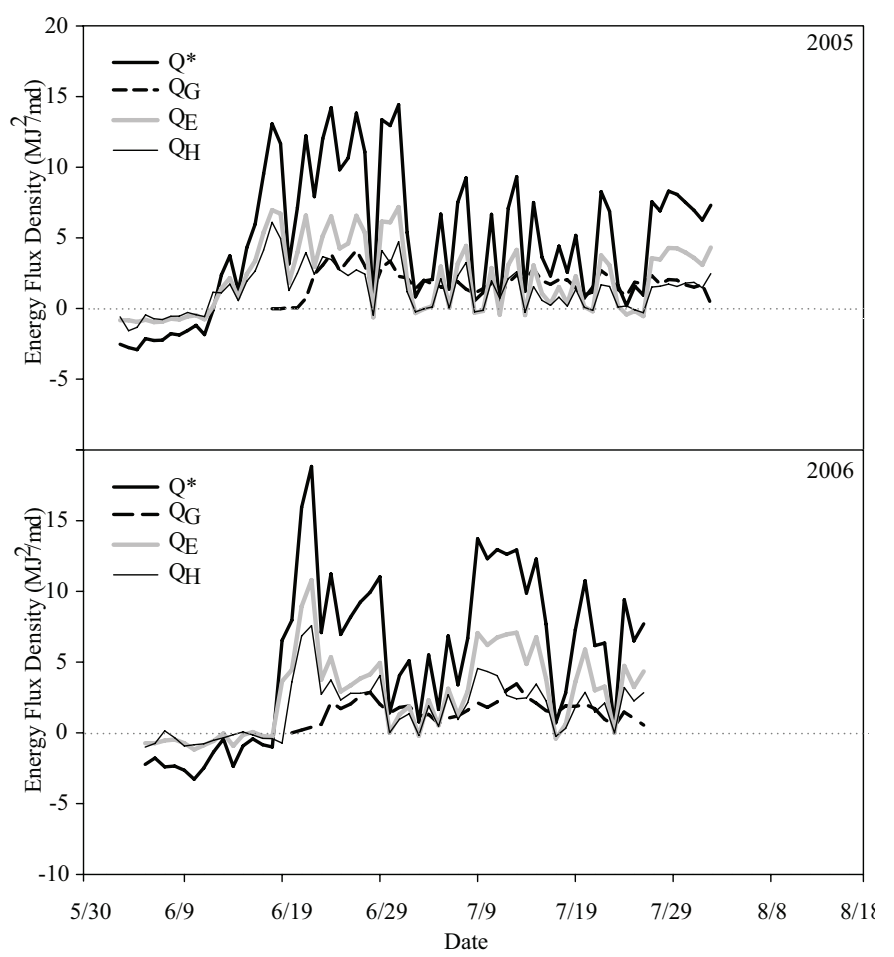

FIG. 6. Surface energy fluxes at the main automatic weather station (AWS) in 2005 and 2006 .

and dry summer in polygonized tundra on Samoilov Island, Siberia.

In both years, the latent heat flux $\left(Q_{E}\right)$ was highest at the beginning of the season, when the ground is saturated and energy receipt is high. At Creswell Bay, daily $\mathrm{Q}_{\mathrm{E}}$ reached $7.54 \mathrm{MJ} / \mathrm{m}^{2} \mathrm{~d}$ in 2005 and $10.86 \mathrm{MJ} / \mathrm{m}^{2} \mathrm{~d}$ in 2006. As the season progressed and soil moisture levels declined or poor weather (fog, low clouds) occurred, $\mathrm{Q}_{\mathrm{E}}$ averaged only 2.17 $\mathrm{MJ} / \mathrm{m}^{2} \mathrm{~d}$ in 2005 and $2.69 \mathrm{MJ} / \mathrm{m}^{2} \mathrm{~d}$ in 2006. Overall, $\mathrm{Q}_{\mathrm{E}}$ consumed $45 \%$ of Q* in 2005 and $49 \%$ in 2006 , a pattern replicated in other studies of northern wetlands (Harazono et al., 1998; Eaton et al., 2001). In terms of water equivalent units, peak estimates were $3.0 \mathrm{~mm} / \mathrm{d}$ in 205 and $4.4 \mathrm{~mm} / \mathrm{d}$ in 2006 . $\mathrm{Q}_{\mathrm{H}}$ responded to temperature and wind conditions and consumed $27 \%$ of net radiation in 2005 and $31 \%$ in 2006 . Sensible heat is significant during the snowmelt period but becomes less so in the post-snowmelt period. Still, it can enhance evaporation by providing energy during periods when radiation levels drop off. Overall, the Bowen ratio is similar in both years (0.62 in 2005 and 0.70 in 2006) and is typical of other wetland environments where the bulk of the energy is consumed by evaporation (Lynch et al., 1999; Eugster et al., 2000; Soegaard et al., 2001).

Regression analysis between net radiation values from the AWS site (x-axis) and the observed ponds (y-axis) showed values of slopes close to $1(p<0.05)$ except for the Bedrock pond, with a slope of $0.89(p<0.05)$ (Table 4$)$. Distinct differences between the sites are highlighted by the $\mathrm{y}$-intercept values $(p<0.05)$. The largest intercept value occurs for the Bedrock pond and the smallest at the
Moraine pond. The application of these relationships in the estimation of site-specific radiation values for 2005 and 2006 showed that $Q^{*}$ receipt was higher at the Bedrock site $\left(8.1 \mathrm{MJ} / \mathrm{m}^{2} \mathrm{~d}\right)$ and lowest at the Moraine pond $(6.8 \mathrm{MJ} /$ $\left.\mathrm{m}^{2} \mathrm{~d}\right)$. Daily total net radiation values were nearly identical at the Coastal $\left(7.6 \mathrm{MJ} / \mathrm{m}^{2} \mathrm{~d}\right)$ and Plateau ponds $\left(7.4 \mathrm{MJ} / \mathrm{m}^{2} \mathrm{~d}\right)$. Evaluation of surface albedo or reflectivity showed some variability amongst sites $(p<0.05)$. The Plateau pond substrate had the lowest average albedo value of $0.09(n=36)$. Such a low albedo could be associated with the blue-green algae community on the pond substrate, which was black in appearance (Munsell code 7.5 YR 5/1). Petzold and Rencz (1975) discovered similar values for fire-disturbed sites that were blackened in color $(\alpha=0.07)$. The albedo values of the Coastal, Bedrock $(n=38)$, and Moraine $(n=32)$ pond substrates were slightly higher, ranging from 0.11 for the Coastal pond $(\mathrm{n}=34)$, and 0.12 for Bedrock and Moraine ponds ( $n=38$ and $n=32$, respectively). Here, lighter colored diatoms and green periphytic communities existed. Werdell and Roesler (2003) recorded similar albedos (0.11) for submerged vegetation in shallow seawater. The low surface albedo and shallow water tables of the Plateau pond led to warmer pond temperatures at the beginning of the season, resulting in enhanced latent heat fluxes and drying of the pond. Higher receipt of $\mathrm{Q}^{*}$ at the Bedrock site resulted from a combination of deeper water tables and high thermal conductivities of coarse rocky substrate that kept the pond temperatures elevated, especially during warm and dry periods in 2005. At the Moraine pond, in addition to low substrate albedo and relatively deep water tables, the connectivity to a stream early in the season and a late-lying snowbed later resulted in the lowest $\mathrm{Q}^{*}$ receipt overall.

\section{Snowcover and Melt}

Snow remains one of the most important inputs of water into Arctic ponds. Table 5 outlines the range in snow depth, snow density, and snow water equivalent of the studied ponds. Overall, ponds contained more snow in 2005 than in 2006. SWE values differed amongst the ponds, with variable snow depths accounting for most of this difference. The Bedrock pond captured more snow than ponds at other sites. In comparison to tundra thaw ponds existing within a polar oasis environment (Woo and Guan, 2006), ponds in this study contained almost twice as much snow in both years, clearly establishing their existence within a polar desert climatic regime.

Pond snowmelt, in terms of timing, melt rate, and duration, was variable in both years in response to shifting climatic conditions and individual snow amounts (see Fig. 7). In 2005, snowmelt commenced on 5 June at the Coastal site and two days later at both the Moraine and Plateau ponds. The Bedrock pond started melting on 8 June, three days after the Coastal site. Melt lasted for about 10 days at all sites. In 2006, steady melting was delayed until about 12 June for most sites and lasted for about 10 days, with 19 days in total from the beginning of the snowmelt. This pattern of 
TABLE 4. Relationship between net radiation at the main automatic weather station (AWS) and each pond site using climate data from the roving weather station (RWS).

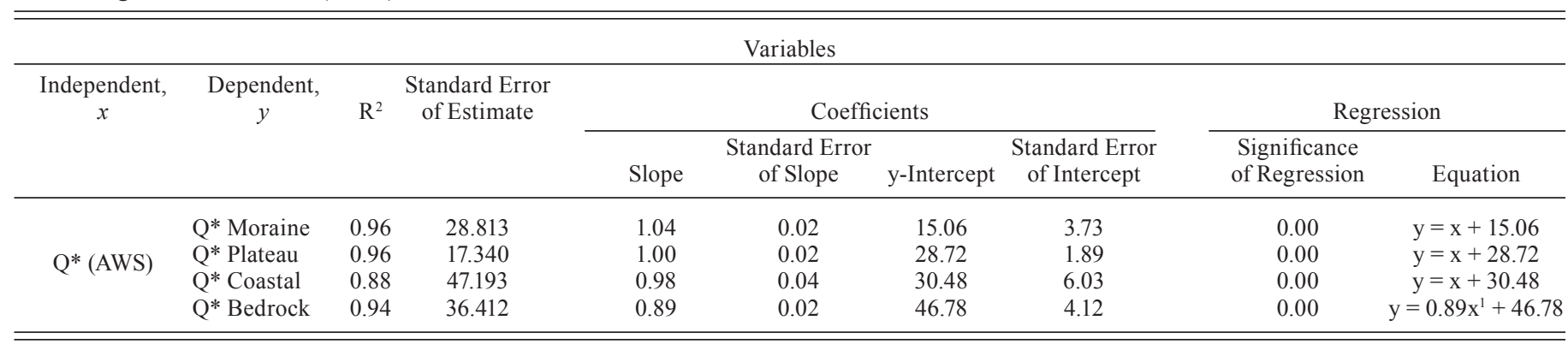

${ }^{1}$ Regression slope is significantly $(p<0.05)$ lower than 1.

TABLE 5. Snow depth, density, and snow water equivalence (SWE) at the study ponds in 2005 and 2006.

\begin{tabular}{|c|c|c|c|c|c|c|c|}
\hline Mean: & 44 & 0.336 & 148 & Mean: & 37 & 0.314 & 115 \\
\hline Max: & 59 & 0.416 & 237 & Max: & 52 & 0.362 & 174 \\
\hline Min: & 33 & 0.265 & 117 & Min: & 25 & 0.226 & 81 \\
\hline Plateau & & & & Plateau & & & \\
\hline Mean: & 48 & 0.305 & 153 & Mean: & 35 & 0.304 & 105 \\
\hline Max: & 63 & 0.341 & 210 & Max: & 51 & 0.366 & 163 \\
\hline Min: & 32 & 0.264 & 103 & Min: & 19 & 0.266 & 59 \\
\hline SD: & 8 & 0.025 & 31 & SD: & 7 & 0.026 & 26 \\
\hline $\mathrm{COV}$ & 0.16 & 0.08 & 0.21 & $\mathrm{COV}$ & 0.21 & 0.08 & 0.25 \\
\hline SD: & 12 & 0.029 & 36 & SD: & 9 & 0.070 & 26 \\
\hline $\mathrm{COV}$ & 0.24 & 0.09 & 0.22 & $\mathrm{COV}$ & 0.24 & 0.22 & 0.22 \\
\hline Pond Snow Storage $\left(\mathrm{m}^{3}, \mathrm{SWE}\right)=225$ & & & & Pond Snow Storage $\left(\mathrm{m}^{3}, \mathrm{SWE}\right)=169$ & & & \\
\hline Bedrock & & & & Bedrock & & & \\
\hline Mean: & 71 & 0.356 & 258 & Mean: & 44 & 0.359 & 163 \\
\hline Max: & 92 & 0.410 & 349 & Max: & 73 & 0.389 & 247 \\
\hline Min: & 45 & 0.276 & 182 & Min: & 18 & 0.318 & 107 \\
\hline SD: & 10 & 0.034 & 47 & SD: & 12 & 0.022 & 43 \\
\hline $\mathrm{COV}$ & 0.14 & 0.10 & 0.18 & $\mathrm{COV}$ & 0.28 & 0.06 & 0.26 \\
\hline Pond Snow Storage $\left(\mathrm{m}^{3}, \mathrm{SWE}\right)=167$ & & & & Pond Snow Storage $\left(\mathrm{m}^{3}, \mathrm{SWE}\right)=105$ & & & \\
\hline
\end{tabular}

${ }^{1} \mathrm{COV}=$ coefficient of variation and $\mathrm{SD}=$ standard deviation. $\mathrm{COV}=\mathrm{SD} / \mathrm{Mean}$.

melt reflects the results reported by Woo and Guan (2006), who indicate a long melt season in 2006 (21 d, 24 May-13 June) due to cooler conditions than the previous year (only $11 \mathrm{~d})$.

\section{Post-Snowmelt: Steady Hydrological Linkages (Moraine Pond)}

Figure 8 indicates the seasonal hydrologic patterns of the studied ponds during the post-snowmelt season, and Figure 9 indicates the pond water balances. Both figures provide a good indication of the range in vulnerability that ponds experience situated in this environment. The Moraine pond resides in a lush vegetated low-gradient catchment with fine-textured soils. It provides a reasonable example of how multiple and persistent linkages with the surrounding catchment ensure positive water storage in years with variable climates (Fig. 8). Despite variable climatic conditions, the water table remains steady and relatively unchanged in both years. Frost table development is similar in 2005 and 2006 but shallower than at other sites, a pattern that similarly emerged in 2004 when a pond survey was conducted across this wetland (Young and Abnizova, 2008). Shallow thaw ensures that water tables remain near the ground surface. Summer rain and snowfall did not increase pond levels much. Only one two-day rainstorm in 2006 (16-17 July, $10.4 \mathrm{~mm}$ ) resulted in a pond level rise of $19 \mathrm{~mm}$. A higher water level response than generated by rain alone suggests 


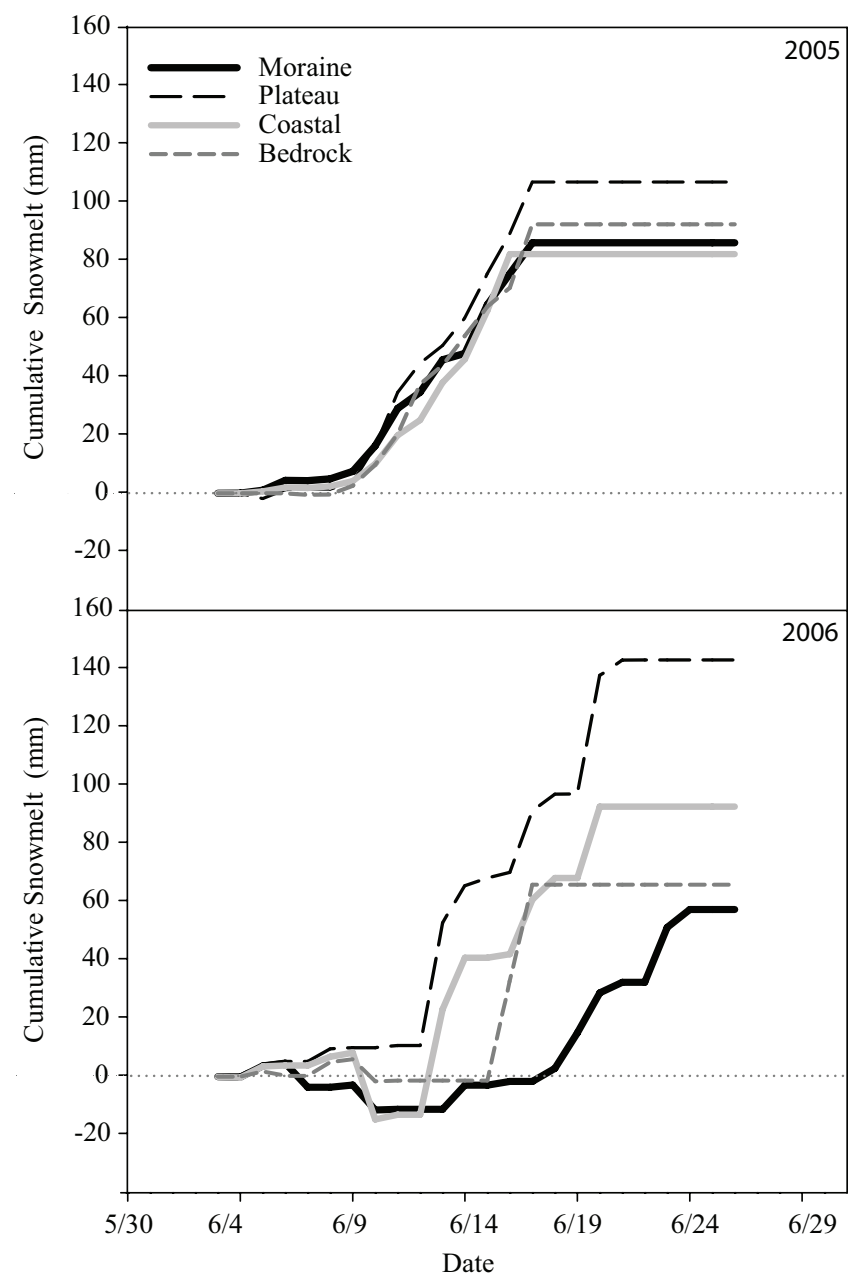

FIG. 7. Observed cumulative snowmelt regime at the pond sites in 2005 and 2006. Negative values in 2006 indicate precipitation gains as a result of snow accumulation.

the addition of water from the surrounding catchment, and this theory is supported by the moist transition zone (see Fig. 10). A similar response was demonstrated in the study by Woo and Mielko (2007), which described a $20-22 \mathrm{~mm}$ rainstorm event in late July that raised the water levels in four study lakes located in a headwater catchment $15 \mathrm{~km}$ north of Yellowknife. Evaporation did not have a strong control on water levels either. Daily rates of evaporation from the Moraine pond (open water) averaged $1.9 \mathrm{~mm} / \mathrm{d}$ in 2005 and $2.2 \mathrm{~mm} / \mathrm{d}$ in 2006. A relatively deep water column, cool temperatures, and higher average seasonal albedo than the Plateau pond reduced energy availability for evaporation. While these evaporation rates are typical of other ponds in both the Subarctic and High Arctic (e.g., Young and Woo, 2003; Woo and Guan, 2006), they are slightly lower than rates for the other ponds in this study. Evaporation totaled $103 \mathrm{~mm}$ by 13 August 2005 and $86 \mathrm{~mm}$ by 26 July 2006 .

The response to precipitation inputs and evaporation losses cannot adequately explain the apparent increase of the water level in the Moraine pond at the beginning of the study season or its general stability throughout the season. It was discovered that the upland stream emptying into the low-lying moraine zone initially provided water to the Moraine pond during the main snowmelt season, when discharges were high (Fig. 10). Elevated stream discharges persisted from 19 June to 22 June 2005, and this flow was associated with a pond level rise of $17 \mathrm{~mm}$. This pattern of pond water recharge is common in Arctic environments and was also noted by Woo and Guan (2006) for a polar oasis area. In our study, upland water dominated water inputs to several tundra ponds during the 2005 snowmelt season but was less important in 2006 because of low snowcover and snowmelt yield.

Field observations suggest that steady water levels are further maintained by the meltwaters issuing from a nearby late-lying snowbed (200 m away) (Fig. 10). According to Young and Woo (2003), the prolonged snowmelt of these snowbeds allows additional meltwater inputs during the post-snowmelt season. This particular snowbed provided meltwater from 25 June to 14 July in 2005 and similarly from 26 June till 13 July in 2006.

The Moraine pond can be considered a sink for subsurface flows throughout the season, and such a hydrologic pattern was common in both 2005 and 2006 (Figs. 8 and 9 ). Very small values of saturated hydraulic conductivity $(0.86 \mathrm{~m} / \mathrm{d})$ associated with the fine material, coupled with a low gradient, give rise to low subsurface inputs. Similar hydraulic conductivity values for peat and loamy sandy soils were found by Beringer et al. (2001) for an Arctic tundra site in the Imnavait Creek watershed, northern Alaska.

Overall, the Moraine pond is able to sustain itself and remain little affected despite variable climatic conditions and a small pond area. The pond lies within a low-lying, well-vegetated, moist catchment that is routinely supplied by meltwater from an upland stream. Once this source of water diminishes, additional meltwater is provided by a nearby late-lying snowbed. Water levels remain steady throughout most of the drying season and are able to sustain most vertical losses - both evaporation and seepage into the ground. Finally, the pond's moist catchment is effective in transferring water into the pond during periods of moderate to heavy rainfall. These various water sources (stream, late-lying snowbed, and runoff from a moist catchment), and especially their timing and duration, vary on a seasonal basis, but they can also be considered complementary to each other, and thus provide a stable hydrologic regime for this Moraine pond type.

\section{Intermittent Hydrologic Linkages: Bedrock and Plateau Ponds}

The Bedrock pond provides a good indication of how ponds respond when subjected to intermittent or limited hydrologic linkages within the surrounding landscape (see Figs. 8 and 9). Deep ground thaw in both years $(>850 \mathrm{~mm})$ encouraged vertical seepage, while evaporation demand was comparable to that of the Moraine pond $(2.4 \mathrm{~mm} / \mathrm{d}$ in 2005 and $2.6 \mathrm{~mm} / \mathrm{d}$ in 2006). Water tables fell but remained steady (at around $175 \mathrm{~mm}$ in 2005 and $140 \mathrm{~mm}$ in 2006) 

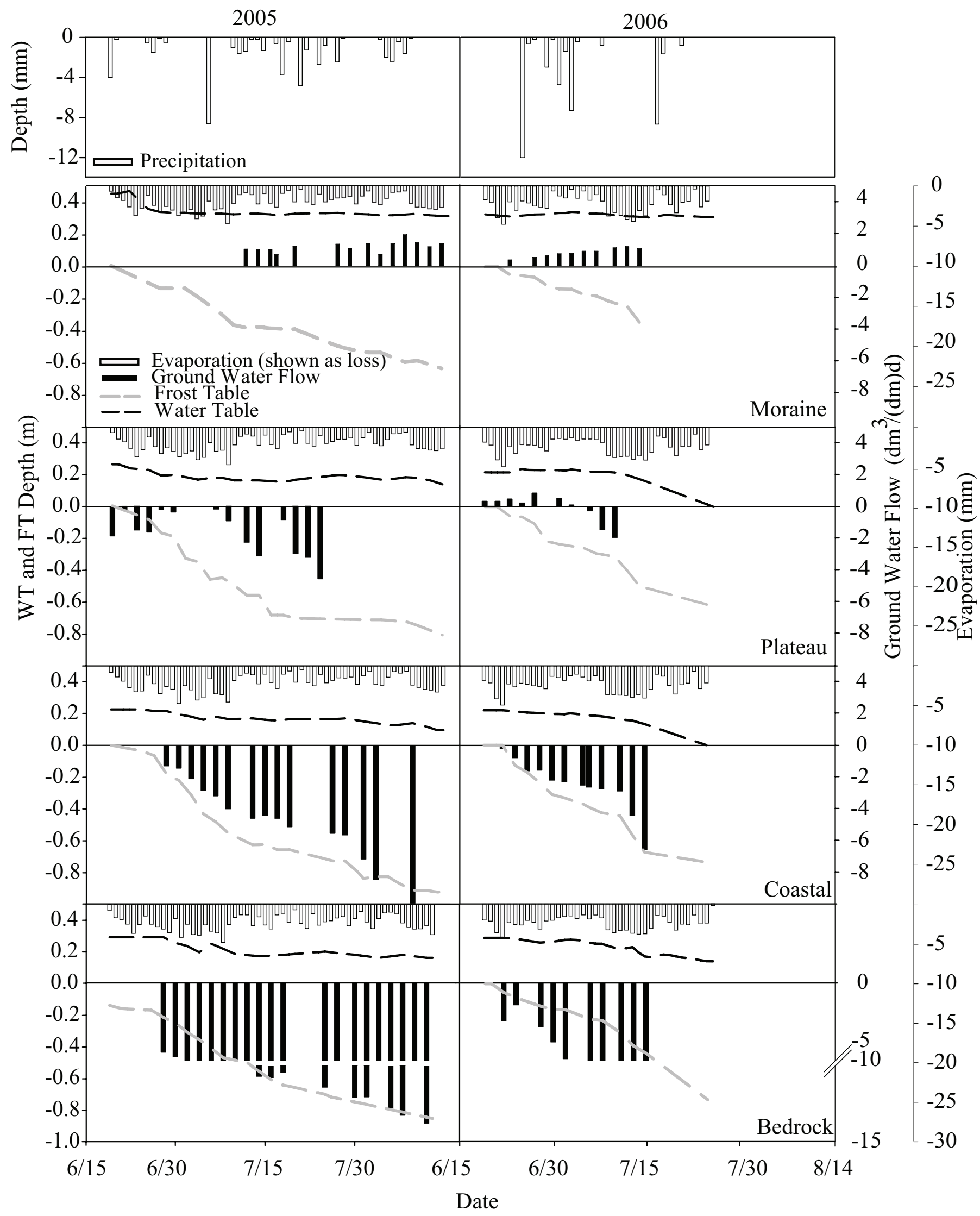

FIG. 8. Post-snowmelt patterns (2005 and 2006) of frost table, water table, evaporation, and groundwater flow at the Moraine, Plateau, Coastal, and Bedrock ponds. Precipitation for 2005 and 2006 is provided at the top of the page to aid in interpretation. Note that groundwater flow is expressed as $\mathrm{dm}^{3} /(\mathrm{dm}) \mathrm{d}$ for graphing purposes. 


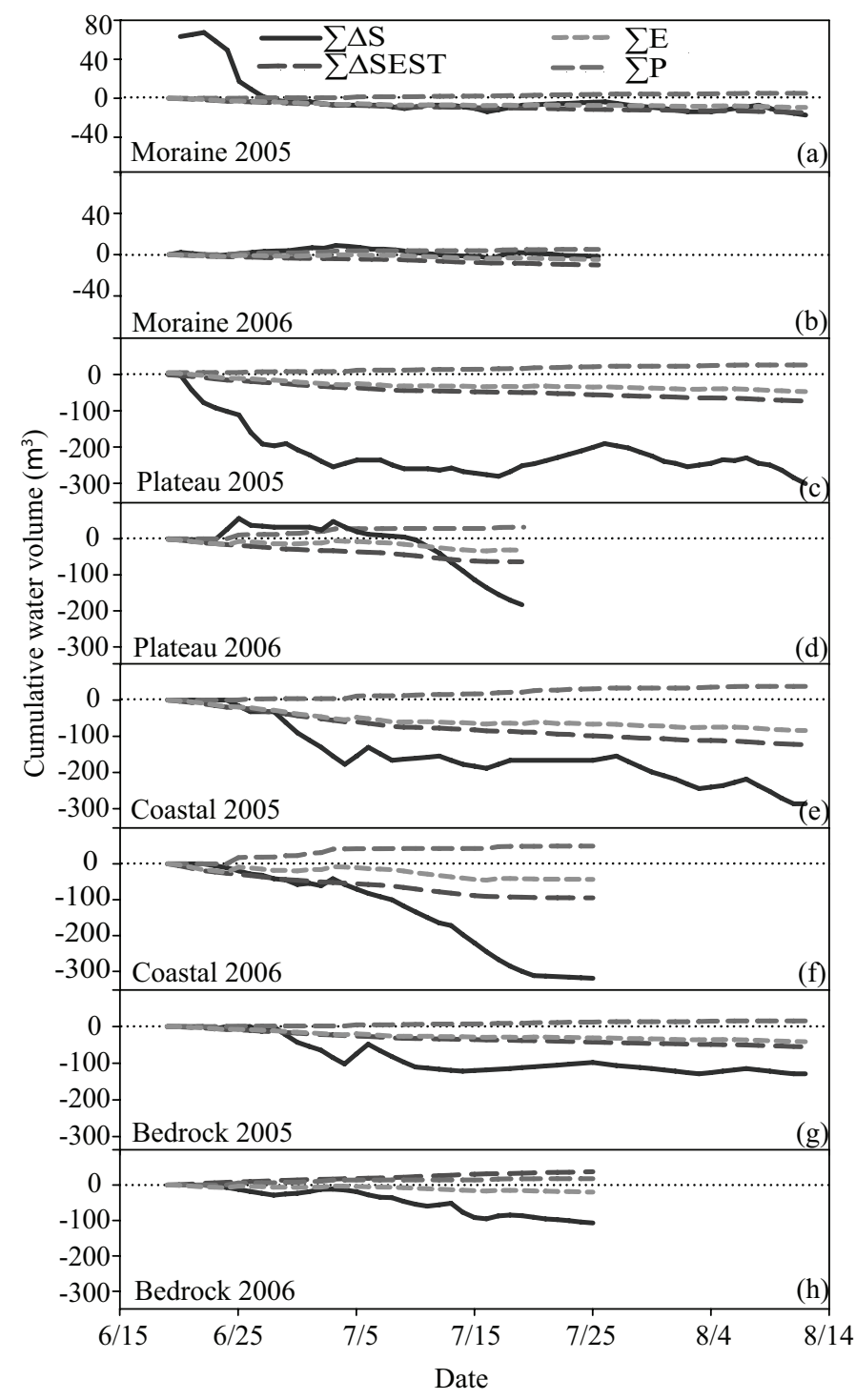

FIG. 9. Post-snowmelt water budgets of study ponds with cumulative measured change $(\Sigma \Delta \mathrm{S})$ and cumulative estimated change $\left(\Sigma \Delta \mathrm{S}_{\mathrm{EST}}\right.$, where $\mathrm{S}_{\mathrm{EST}}=$ precipitation minus evaporation). Note that the vertical scale for the Moraine site is different from the scale for the other pond sites.

from 10 July onwards. The pond's setting is one of the main factors for its sustainability. It is found in a well-defined topographic depression, which traps more snow than the flat-bottom ponds (i.e., Coastal, Plateau), which are more exposed to winds. A greater accumulation of snow at the Bedrock pond site delays ground thaw, shortens the evaporation period, and provides sufficient water after snowmelt to meet large evaporation demands and any subsurface losses through vertical drainage. The pond also receives water supply from its surrounding catchment during rain events. For instance a single rain event, $8.6 \mathrm{~mm}$ on 5 July 2005, resulted in a dramatic water level rise of $55 \mathrm{~mm}$, suggesting inflow from the surrounding catchment. However, a twoday rain event in the middle of 2006 (16-17 July, $13.1 \mathrm{~mm})$ raised pond levels by only $16 \mathrm{~mm}$. This contrast suggests that the timing of rainfall and the antecedent moisture conditions of the catchment are important when considering

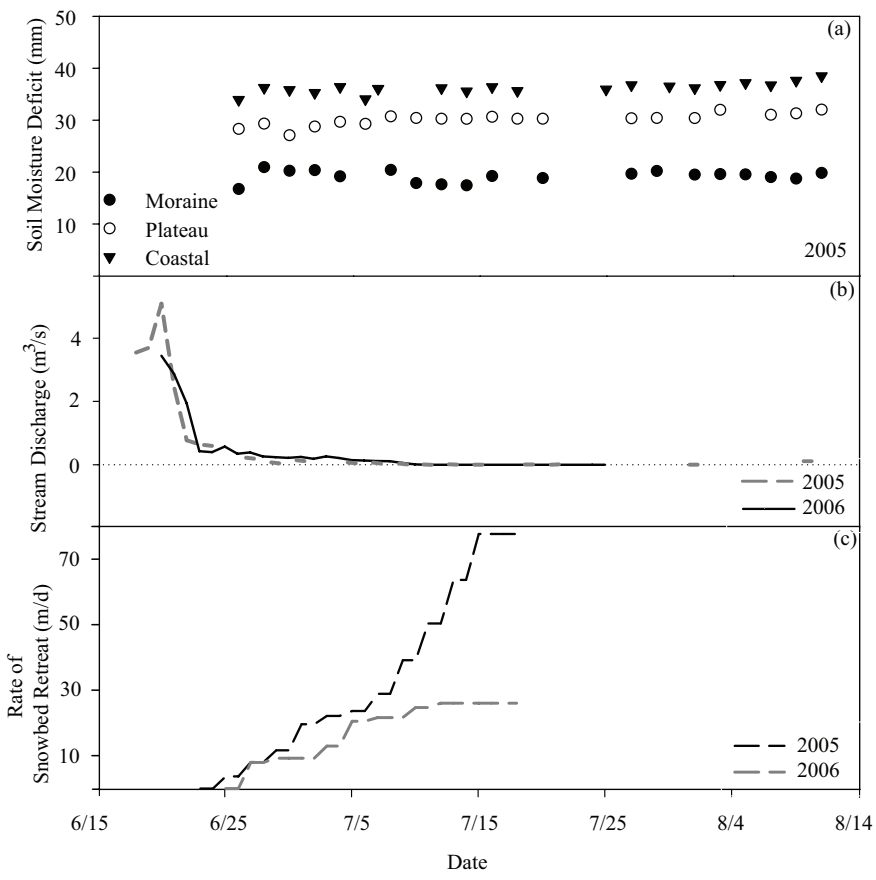

FIG. 10. (a) Post-snowmelt surface soil moisture deficit in the pond transition zone in 2005, (b) stream discharge pattern for the upland stream in 2005 and 2006, and (c) retreat of a late-lying snowbed located near the Moraine pond (2005 and 2006).

the potential contribution of a rainfall event. Later on in the summer, deep thaw, together with a dry substrate, ensures that most rainfall of the small and moderate type goes into storage and is not nearly as effective in raising water levels. However, extreme rainfalls do occur, and on occasion these can raise pond water levels up to snowmelt recharge levels (e.g., Kane and Yang, 2004; Woo and Guan, 2006; Young and Abnizova, 2008).

Other sources of water complement catchment conditions to deliver water to the ponds. For example, warmer conditions in 2006 generated ground ice melt, which raised pond levels by $11 \mathrm{~mm}$ on July 13 (Fig. 8). No rain occurred during this time, so ground ice melt is the only source possible. According to Young and Woo (2000), ground ice can be a significant storage term in the water balance equation and can be an important source of water after snowmelt. Young and Woo (2000) found that the largest contribution of ground ice moisture occurred right after snowmelt and came from ice-rich organic soils. Because the water pulse occurs later in the season, ground ice-melt likely originates from an ice-rich zone near the interface of the active layer and the uppermost portion of the permafrost table. The fact that this source was not evident in 2005 suggests that its reliability is intermittent and possibly limited, especially if a series of warm, dry years deplete it. When this water supply does appear, the gravelly and porous nature of the catchment with its high flow rate ( 26 to $2600 \mathrm{~m} / \mathrm{d}$ ) ensures that water is delivered to the pond quickly.

Overall, the Bedrock pond does not have a reliable hydrologic supply like the Moraine pond. Subsurface flow is significant, reaching up to $0.13 \mathrm{~m}^{3} /$ day per unit width, 
much more than at the other study ponds. However, depending on timing and the antecedent conditions of the catchment, moderate rainfall can lead to substantial increases in water level. The porous and highly conductive nature of the catchment enhances this inflow. Ground ice melt is an additional source when deeper thaw encounters the ice-rich permafrost table. However, this water supply is not assured every year and could be depleted during several consecutive warm, dry years. The rate at which it might build up again under cooler, wetter conditions is not known for this environment (Young, 2006).

The Plateau pond provides another example of a pond with limited linkages to the landscape so that its sustainability depends upon climatic events (wetting, drying episodes) and catchment conditions. Given its location on a plateau, fully exposed to winds, the Plateau pond did not trap as much seasonal snow, only about $50 \%$ of the amount trapped by the Bedrock pond. But like the Bedrock pond, the coarse materials here give rise to rapid thaw. Ground thaw reached a depth of $810 \mathrm{~mm}$ below the ground by 14 August 2005 and was estimated to be $772 \mathrm{~mm}$ in 2006. A steep temperature gradient following snowmelt, coupled with moist sand, is effective in transferring heat downwards. According to Osterkamp and Romanovsky (1996), moist sandy silt materials can reach thermal conductivity values of $2.20-3.39$ $\mathrm{W} / \mathrm{mK}$. Sizeable drops in water tables in both years can be associated with this deep, rapid thaw and enhanced evaporation. Evaporation rates averaged $2.1 \mathrm{~mm} / \mathrm{d}$ in 2005 and $2.5 \mathrm{~mm} / \mathrm{d}$ in 2006, slightly higher than the Moraine pond. In fact, this pond went dry in mid-July 2006. A blackened substrate here encourages radiation absorption, which can enhance deep thaw and elevate evaporation rates (Oke, 1987). Field observations in 2005 and 2006 suggested that no surface flow occurred here. Instead, moderate values of $\mathrm{k}_{\mathrm{s}}(1.6 \mathrm{~m} / \mathrm{d})$, typical of loamy sand, resulted in substantial groundwater losses that increased towards the end of the study season, reaching $0.04 \mathrm{~m}^{3} / \mathrm{d}$ per unit width by 12 August 2005 and $0.01 \mathrm{~m}^{3} / \mathrm{d}$ per unit width by 14 July 2006 . These losses further deprived the pond of water.

As in the Bedrock pond, summer rain and snow appear to modify water levels, but their potential impact depends on their timing and magnitude, as well as the antecedent conditions of the pond catchment. For instance, a continuous seven-day rain event $(11.9 \mathrm{~mm})$ that lasted from 19 June to 26 June 2005 resulted in a $30 \mathrm{~mm}$ rise in pond water level. Similarly, at the beginning of the 2006 season, a large rain event on 25 June $(12.2 \mathrm{~mm})$ led to a $23 \mathrm{~mm}$ rise in pond level. But a moderate event on 5 July $2005(8.6 \mathrm{~mm})$ resulted in a water level rise of only $10 \mathrm{~mm}$. During a dry spell in 2006, 5-16 July, pond level declined more than $60 \mathrm{~mm}$. However, a sizeable rain event on $17 \mathrm{July}(8.8 \mathrm{~mm})$ had little effect, which suggests that the pond and its catchment had a large storage capacity that went unfilled. This theory is supported by a substantial soil moisture deficit in the transition zone $(31 \mathrm{~mm}$ ) in both 2005 and 2006 (see Fig. 10). These findings suggest that frequent but minor precipitation events towards the latter part of the thawing season may result in decreased storage capacity in catchments, priming the site for large events that may contribute to pond-to-catchment hydrologic connectivity (Kane and Yang, 2004; Woo and Mielko, 2007).

\section{Detrimental Hydrologic Linkages: Coastal Pond}

The Coastal pond has strong links with the landscape through the presence of nearby frost cracks, both minor and major in form. Frost cracks can deliver meltwater or rainwater to a site, but in this situation they help to deprive the pond of water. Consequently, their presence can be considered to be a liability.

Of the four ponds studied, the Coastal pond can be considered the most vulnerable to desiccation. The coarse substrate thaws easily at the end of snowmelt, and the water table drops accordingly. Its sandy soils, like those at the Plateau site, generally have low ice contents due to low porosity and high thermal conductivity values $(2.20-3.39 \mathrm{~W} / \mathrm{mK})$ that encourage thaw (e.g., Woo and Steer, 1983; Osterkamp and Romanovsky, 1996). Evaporation rates were similar to those of the Bedrock and Plateau ponds $(2.2 \mathrm{~mm} / \mathrm{d}$ in 2005 and $2.6 \mathrm{~mm}$ in 2006) owing to a darkened substrate that increased radiation absorption and warmed pond waters $\left(\mathrm{Q}_{\mathrm{WH}}\right)$, supplying heat for further evaporation (Oke, 1987).

As for the other ponds, rainfall must occur at the right time in order to be effective (see Figs. 8 and 9). Low precipitation amounts at the beginning of the 2005 season coincide with water level decline, indicating that water inputs are not sufficient to maintain water losses. This is not surprising considering the dry conditions in the catchment. The soil moisture deficit of the catchment supports this pattern (see Fig. 10a). But a later rain event $(8.6 \mathrm{~mm})$ resulted in a $20 \mathrm{~mm}$ rise in water level, suggesting that the catchment was primed and could readily respond to additional inputs of water. This observation is supported by Marsh and Woo (1977), who found that large rainfall events can contribute significant lateral inputs to a pond when the active layer in the transitional zone of the catchment is fully saturated. Similarly, a prolonged rain event at the end of the 2005 season $(6.7 \mathrm{~mm}, 2-7$ August) resulted in a $15 \mathrm{~mm}$ rise. In this case, temperature and radiation levels were lower and evaporation rates were suppressed, allowing moisture levels to creep up (Young and Woo, 1997).

Priming of the basin before much runoff is also evident from the 2006 results. Greater frequency and longer duration of precipitation resulted in more dramatic responses in water levels. A large rain event $(14.2 \mathrm{~mm}$, from 30 June to 4 July) did not affect the pond right away. Water levels increased by $3 \mathrm{~mm}$ on the second day ( $4.8 \mathrm{~mm}$ of rain), but the highest increase did not occur until the second-last day when $7.4 \mathrm{~mm}$ of rain fell and pond levels jumped $8 \mathrm{~mm}$. Overall, the Coastal transition zone possessed the highest soil moisture deficit of all the sites, ranging from 32 to $37 \mathrm{~mm}$, suggesting that it is not particularly conducive to surface flow compared to the Moraine catchment. 
Groundwater outflow was significant in both seasons (see Figs. 8 and 9). These losses ranged from $5.5 \times 10^{-5}$ to $4.9 \times 10^{-2} \mathrm{~m}^{2} / \mathrm{d}$ per unit width and were smaller than those of the Plateau site, reflecting a reduced hydraulic gradient $(0.002 \mathrm{~m} / \mathrm{m})$ with the surrounding catchment. However, large groundwater losses from the pond occurring later in the season were linked to a nearby frost crack. Presence of this frost crack downslope of the pond has a major effect on pond water tables. It creates a steep hydraulic gradient $(0.32 \mathrm{~m} / \mathrm{m})$ between the pond and frost crack, generating large subsurface losses from the pond, e.g., a seasonal average of $1.5 \times 10^{-2} \mathrm{~m}^{2} / \mathrm{d}$ per unit width (2005). However, the largest losses from the pond to the frost crack were observed late in the 2006 season. They occurred when the frost crack became desiccated and resulted in drying of the Coastal pond by 25 July (Abnizova and Young, 2008).

Relatively large subsurface losses from the Coastal pond result from a rapid and deep thaw of sandy soil, which enhances vertical water seepage. In addition, topographically lower water levels in the frost crack set up a steep hydraulic gradient that, together with large hydraulic conductivity values for sand, enhances subsurface flow out of the pond. Finally, a dry transition zone around the pond is not particularly effective in funneling water into this pond during rain events.

\section{CONCLUSIONS}

Ponds in the High Arctic are identified as hydrogeomorphic units created from topographic depressions in the landscape that ultimately retain water, which then become pond storage (Marsh and Woo, 1977). Evaluation of the water storage in several ponds near Creswell Bay, Somerset Island, located in a polar desert climate, reveals the factors that are important in the sustainability of these freshwater ecosystems.

Pond water storage at the beginning of the thaw period is found to be highly dependent on the end-of-winter snow accumulation, which provides large amounts of water to recharge the pond storage depleted by the end of the previous thaw season. Snowcover amounts and distribution are especially important in the sustainability of ponds that are not well connected to a broader hydrological system. For example, the Bedrock pond was highly dependent on large quantities of snow to provide enough water to sustain itself through the season.

The relative hydrological isolation and large subsurface losses at the Coastal and Plateau sites indicate that these ponds are highly dependent on snow and rain as the major source of water. The timing of rainfall was also critical in the sustainability of these ponds, since rain helped at times to revive them following periods of drought. The Bedrock pond was also vulnerable to the precipitation regime, but unlike the ponds at the Coastal and Plateau sites, it had positive subsurface contributions associated with rain inputs and ground ice melt from the surrounding catchment.
Overall, precipitation in the form of snow and rain remains important for pond sustainability in these catchments, since ponds require sufficient water storage to sustain vertical losses to evaporation and seepage.

Decline in water level due to lateral outflow accounted for large changes in storage for the Bedrock, Coastal, and Plateau sites. Large groundwater losses from the ponds at the Coastal and Plateau sites resulted in desiccation of ponds that were shallow in depth, with moderate-to-steep hydraulic gradients and deep thawed zones. The presence of a frost crack downslope of the Coastal pond was a special landscape feature that encouraged water outflow instead of inflow. It is possible that additional contributions of subsurface inflow from the surrounding catchment at the Bedrock site minimized water losses; otherwise, this pond might have dried out like the others in 2006.

Dependence of a pond on the connectivity to other water sources in its catchment is essential and provides for its sustainability in years with variable climate. The Moraine pond site provides a good example. The Moraine pond benefitted from a moist catchment that routed excess surface water generated from rainfall into the pond. Its connectivity to a stream and late-lying snowbank demonstrates the importance of having a variety of water sources that can sustain ponds through warm, dry episodes. For example, large amounts of snow and earlier melt in 2005 resulted in higher stream discharge, which provided water to many ponds within the low-lying moraine zone. Lower snow amounts in 2006 and delayed melt resulted in lower stream discharge and limited recharge of ponds. In such a case, the pond's additional link to the late-lying snowbed acts as a reliable backup in drier years.

Overall, this study has shown that even though ponds may exist under a similar climatic regime within a wetland complex, their hydrological sustainability is not the same. Understanding a pond's water budget is important for detecting the thresholds or factors leading to a pond's sustainability or demise under variable climatic conditions. Each pond's hydrological inputs and losses are governed by a system of factors including the pond catchment (e.g. topography, soils, pond substrate materials, and vegetation conditions), presence or absence of hydrologic linkages, and different responses because of climate variability (2005 vs. 2006). These factors need to be kept in mind as we consider how these wetland complexes may evolve in the future as a result of climate warming.

\section{ACKNOWLEDGEMENTS}

This research was made possible by grants from the Natural Sciences and Engineering Research Council of Canada and the Northern Scientific Training Program. Excellent logistical support was provided by the Polar Continental Shelf Project. A special thanks to Markus Anastasiades for his unconditional support in the field. We would like to acknowledge two anonymous reviewers who provided helpful advice that has greatly improved the manuscript. 


\section{REFERENCES}

Beringer, J., Lynch, A.H., Chapin, F.S., III, Mack, M., and Bonan, G.B. 2001. The representation of Arctic soils in the land surface model: The importance of mosses. Journal of Climate 14:3324-3335.

Black, C.A. 1965. Methods of soil analysis. Monograph Series 9. Madison, Wisconsin: American Society of Agronomy. 1572 p.

Boike, J., Wille, C., and Abnizova, A. 2008. Climatology and summer energy and water balance of polygonal tundra in the Lena River Delta, Siberia. Journal of Geophysical Research 13, G03025, doi:10.1029/2007JG000540.

Bowling, L.C., Kane, D.L., Gieck, R.E., Hinzman, L.D., and Lettenmaier, D.P. 2003. The role of surface storage in a lowgradient Arctic watershed. Water Resources Research 9(4), 1087, doi:10.1029/2002WR001466.

Brown, L., and Young, K. 2006. Assessment of three mapping techniques to delineate lakes and ponds in a Canadian High Arctic wetland complex. Arctic 59:283-293.

Dyke, A. 1983. Quaternary geology of Somerset Island, District of Franklin. Memoir 404. Ottawa: Geological Survey of Canada. $32 \mathrm{p}$.

Eaton, A.K., Rouse, W.R., Lafleur, P.M., Marsh, P., and Blanken, P.D. 2001. Surface energy balance of the western and central Canadian Subarctic: Variations in the energy balance among five major terrain types. Journal of Climate 14:3692-3703.

Environment Canada. 2008. Canadian climate normals or averages 1971-2000. http://climate.weatheroffice.gc.ca/climate_normals /index_e.html/.

Eugster, W., Rouse, W.R., Pielke, R.A., Sr., McFadden, J.P., Baldocchi, D.D., Kittel, T.G.F., Chapin, F.S., III, et al. 2000. Land-atmosphere energy exchange in Arctic tundra and boreal forest: Available data and feedbacks to climate. Global Change Biology 6:84-115.

Fitzgerald, D., and Riordan, B. 2003. Permafrost and ponds. Agroborealis 35(1):30-35.

Glenn, M.S., and Woo, M.K. 1997. Spring and summer hydrology of a valley-bottom wetland, Ellesmere Island, Northwest Territories, Canada. Wetlands 17:321-329.

Halliwell, D.H., and Rouse, W.R. 1987. Soil heat flux in permafrost: Characteristics and accuracy of measurement. Journal of Climatology 7:571 -584, doi:10.1002/joc.3370070605.

Harazono, Y., Yoshimoto, M., Mano, M., Vourlitis, G.L., and Oechel, W.C. 1998. Characteristics of energy and water budgets over wet sedge and tussock tundra ecosystems at North Slope in Alaska. Hydrological Processes 12:2163-2183.

Heron, R., and Woo, M.K. 1978. Snowmelt computations for a High Arctic site. Proceedings of the 35th Eastern Snow Conference, Hanover, New Hampshire. 162-172.

Kane, D.L., and Carlson, R.E. 1973. Hydrology of the central Arctic river basins of Alaska. Institute of Water Resources Report 41, Fairbanks: University of Alaska. 51 p.

Kane, D.L., and Yang, D., eds. 2004. Northern research basins water balance. IAHS Publication 290. International Association of Hydrological Sciences 290. Wallingford, United Kingdom: IAHS. $271 \mathrm{p}$.
Keatley, B.E., Douglas, M.S.V., and Smol, J. 2007. Limnological characteristics of a High Arctic oasis and comparisons across northern Ellesmere Island. Arctic 60:294-308.

Latour, P.B., Machtans, C.S., and Beyersbergen, G.W. 2005. Shorebird and passerine abundance and habitat use at a High Arctic breeding site: Creswell Bay, Nunavut. Arctic 58: $55-65$.

Luthin, J.N. 1966. Drainage engineering. New York: Wiley. $250 \mathrm{p}$.

Lynch, A.H., Chapin, F.S., III, Hinzman, L.D., Wu, W., Lilly, E., Vourlitis, G., and Kim, E. 1999. Surface energy balance on the Arctic tundra: Measurements and models. Journal of Climate 12:2585-2606.

Marsh, P., and Woo, M.K. 1977. The water balance of a small pond in the High Arctic. Arctic 30:109-117.

Mendez, J., Hinzman, L.D., and Kane, D.L. 1998. Evapotranspiration from a wetland complex on the Arctic coastal plain of Alaska. Nordic Hydrology 29:303-330.

Nogrady, T., and Smol, J.P. 1989. Rotifers from five High Arctic ponds Cape Herschel, Ellesmere Island, N.W.T. Hydrobiologia 173:231-242.

Oke, T.R. 1987. Boundary layer climates, 2nd ed. Cambridge: Cambridge University Press and Routledge. 435 p.

Osterkamp, T.E., and Romanovsky, V.E. 1996. Characteristics of changing permafrost temperatures in the Alaskan Arctic, U.S.A. Arctic and Alpine Research 28:267-273.

Petzold, D.E., and Rencz, A.N. 1975. The albedo of selected subarctic surfaces. Arctic and Alpine Research 7(4):393-398.

Price, A.G., and Dunne, T. 1976. Energy balance computations of snowmelt in a subarctic area. Water Resource Research 12:686-694.

Prowse, T.D., and Owens, I.F. 1982. Energy balance over melting snow, Craigieburn Range, New Zealand. Journal of Hydrology (The New Zealand Hydrological Society) 21:133-147.

Rosenberry, D.O., Stannard, D.I, Winter, T.C., and Martinez, M.L. 2004. Comparison of 13 equations for determining evapotranspiration from a prairie wetland, Cottonwood Lake Area, North Dakota, USA. Wetlands 24:483-497.

Rust, B.R., and Coakley, J.P. 1970. Physico-chemical characteristics and postglacial desalination of Stanwell-Fletcher Lake, Arctic Canada. Canadian Journal of Earth Sciences 7:900-911.

Rydén, B.E. 1977. Hydrology of Truelove Lowland. In: Bliss, L.C., ed. Truelove Lowland, Devon Island, Canada: A High Arctic ecosystem. Edmonton: University of Alberta Press. 107-136.

Smith, L.C., Sheng, Y., MacDonald, G.M., and Hinzman, L.D. 2005. Disappearing Arctic lakes. Science 308:1429, doi:10.1126/ science.1108142.

Smithson, P., Briggs, D., Atkinson, K., and Addison, K. 2002. Fundamentals of the physical environment, 3rd ed. Routledge. $627 \mathrm{p}$.

Smol, J.P., and Douglas, M.S.V. 2007. Crossing the final ecological threshold in High Arctic ponds. Proceedings of the National Academy of Sciences 104:12395-12397.

Soegaard, H., Hasholt, B., Friborg, T., and Nordstroem, C. 2001. Surface energy- and water balance in a High Arctic environment in NE Greenland. Theoretical and Applied Climatology 70: 35-51, doi:10.1007/s007040170004. 
Stewart, R.B., and Rouse, W.R. 1977. Substantiation of the Priestley and Taylor parameter $\alpha=1.26$ for potential evaporation in high latitudes. Journal of Applied Meteorology 16(6):649-650, doi:10.1175/1520-0450(1977)016<0649:SOTPAT>2.0.CO;2.

Thompson, H.A. 1967. The climate of the Canadian Arctic. In: Canada Year Book 1967. Ottawa: Dominion Bureau of Statistics. 32 p.

Werdell, P.J., and Roesler, C.S. 2003. Remote assessment of benthic substrate composition in shallow waters using multispectral reflectance. Limnology and Oceanography 48:557-567.

Woo, M.K. 1997. A guide for ground based measurement of the Arctic snow cover. Canadian Snow Data CD. Downsview, Ontario: Meteorological Service of Canada. http: www.ccin. ca/datasets/snowcd/docs/1999/DOCUMENTS/WOO.PDF.

Woo, M.K., and Guan, X.J. 2006. Hydrological connectivity and seasonal storage change of tundra ponds in a polar oasis environment, Canadian High Arctic. Permafrost and Periglacial Processes 17:309-323.

Woo, M.K., and Mielko, C. 2007. An integrated framework of lakestream connectivity for a semi-arid, subarctic environment. Hydrological Processes 21:2668-2674, doi:10.1002/hyp.6789.

Woo, M.K., and Ohmura, A. 1997. The Arctic Islands. In: Bailey, W.G., Oke, T.R., and Rouse, W.R., eds. The surface climates of Canada. Montreal and Kingston: McGill-Queen's University Press. 172-197.

Woo, M.K., and Steer, P. 1983. Slope hydrology as influenced by thawing of the active layer, Resolute, N.W.T. Canadian Journal of Earth Sciences 20(6):978-986.

Woo, M.K., and Young, K.L. 1997. Hydrology of a small drainage basin with polar oasis environment, Fosheim Peninsula, Ellesmere Island, Canada. Permafrost and Periglacial Processes 8(3):257-277.

. 2003. Hydrogeomorphology of patchy wetlands in the High Arctic polar desert environment. Wetlands 23(2): 291-309, doi:10.1672/8-20.
2006. High Arctic wetlands: Their occurrence, hydrological characteristics and sustainability. Journal of Hydrology 320(3-4):432-450.

Woo, M.K., Heron, R., and Steer, P. 1981. Catchment hydrology of a High Arctic lake. Cold Regions Science and Technology 5:29-41.

Woo, M.K., Young, K.L., and Brown, L. 2006. High Arctic patchy wetlands: Hydrologic variability and their sustainability. Physical Geography 27(4):297-307, doi:10.2747/0272-3646.27. 4.297.

Yoshikawa, K., and Hinzman, L.D. 2003. Shrinking thermokarst ponds and groundwater dynamics in discontinuous permafrost near Council, Alaska. Permafrost and Periglacial Processes $14: 151-160$.

Young, K.L. 2006. Assessment of snow storage and ground ice melt in High Arctic environments. Hydrological Processes 20:2643-2645.

Young, K.L., and Abnizova, A. 2008. Hydrologic status of High Arctic ponds in a continuous permafrost environment, Somerset Island, Nunavut Canada. Proceedings of the 9th International Permafrost Conference, 29 June-3 July 2008, University of Alaska, Fairbanks. 2003-2008.

Young, K.L., and Lewkowicz, A.G. 1990. Surface energy balance of a perennial snowbank, Melville Island, Northwest Territories, Canada. Arctic and Alpine Research 22:290-301.

Young, K.L., and Woo, M.K. 1997. Modeling net radiation in a High Arctic environment using summer field camp data. International Journal of Climatology 17:1211-1229.

- 2000. Hydrological response of a patchy High Arctic wetland. Nordic Hydrology 31:317-338.

-2003. Thermo-hydrological responses to an exceptionally warm, dry summer in a High Arctic environment. Nordic Hydrology 34:51-70.

Young, K.L., Woo, M.K., and Edlund, S.A. 1997. Influence of local topography, soils, and vegetation on microclimate and hydrology at a High Arctic site, Ellesmere Island, Canada. Arctic and Alpine Research 29:270-284. 